Summer 2003

\title{
Lessons from Stockholm: Evaluating the Global Convention on Persistent Organic Pollutants
}

Andrew J. Yoder

Indiana University School of Law

Follow this and additional works at: https://www.repository.law.indiana.edu/ijgls

Part of the Environmental Law Commons, and the International Law Commons

\section{Recommended Citation}

Yoder, Andrew J. (2003) "Lessons from Stockholm: Evaluating the Global Convention on Persistent Organic Pollutants," Indiana Journal of Global Legal Studies: Vol. 10 : Iss. 2 , Article 5.

Available at: https://www.repository.law.indiana.edu/ijgls/vol10/iss2/5

This Note is brought to you for free and open access by the Law School Journals at Digital Repository @ Maurer Law. It has been accepted for inclusion in Indiana Journal of Global Legal Studies by an authorized editor of Digital Repository@Maurer Law. For more information, please contactrvaughan@indiana.edu.

\section{$\Psi$}

JEROME HALL LAW LIBRARY

INDIANA UNIVERSITY

Maurer School of Law
Bloomington 


\title{
Lessons from Stockholm: Evaluating the Global Convention on Persistent Organic Pollutants
}

\author{
ANDREW J. YODER
}

\section{INTRODUCTION}

On May 22, 2001, representatives from over 120 countries signed a new treaty in Stockholm, Sweden, regulating the "dirty dozen" persistent organic pollutants (POPs) — some of the most dangerous chemicals in the world.' POPs are hardy, toxic chemicals that persist in the environment, wreaking biological havoc in animals and people, to an extent not yet completely understood by scientists. The Stockholm Convention-the first global agreement to seek to ban an entire class of chemicals because of their effects on human health-calls for immediate or long-term elimination of twelve highly toxic chemicals, including PCBs, DDT, and dioxins. ${ }^{2}$ This treaty promises to be one of the main environmental achievements in the decade following the 1992 Rio Earth Summit, articulating principles for a less toxic world, including release prevention, reduction of toxic stockpiles, use of less-dangerous substitutes, and the need for precaution in dealing with toxics generally. ${ }^{3}$ The POPs Convention also takes a proactive approach to toxics management, focusing on elimination of pesticides and other POPs at their source, rather than through "end-of-the-pipe" controls frequently employed by other environmental statutes and treaties. Particularly remarkable is the broad support the treaty has enjoyed among governments, public health officials, environmentalists, and affected industries.

The success of the POPs negotiations, especially in light of the strong debate over certain portions of the treaty text, is encouraging and promises success for

\footnotetext{
* J.D./M.P.A candidate, Indiana University School of Law and School of Public \& Environmental Affairs, 2004. I wish to express my gratitude to John Applegate and Glen Wiser for their inspiration and support in the writing of this Note. Further, I would like to warmly thank Morag Carter, Richard A. Liroff, Anne Platt McGinn, and Cynthia Palmer Olsen for their patient advice and thoughtful comments throughout the processes of drafting and revision.

1. Stockholm Convention on Persistent Organic Pollutants, May 22, 2001, 40 I.L.M. 532 [Stockholm Convention or POPs Convention].

2. See International POPs Elimination Network (IPEN), POPs: The Birth of a Public Health Treaty, at http:/www.ipen.org.

3. Anne Platt McGinn, Reducing Our Toxic Burden, in State of The World 2002, at 75 (2002).
} 
the regime at the implementation stage. The way that negotiators resolved their differences and reached consensus at Stockholm holds lessons not only for future toxics treaties, but also for multilateral environmental agreements (MEAs) generally. This paper focuses on the story of the POPs negotiations, the treaty they generated, and the lessons that can be learned from that experience. In Part II, I present the problem of persistent organic pollutants, discussing their global impacts on human and animal health, particularly on women and young children. In Part III, I discuss the growth of international concern over POPs, spurred by research into endocrine disruption and other health effects, and the way that this awareness developed into a mandate to construct a global POPs treaty. In Part IV, I discuss tensions inherent in environmental treaty negotiations, examine the negotiating stages of the POPs treaty process, and highlight important debates between participants. In Part V, I examine factors that suggest the likely success of the POPs treaty, focusing on aspects of the negotiation process that apply broadly in other global, environmental contexts, and conclude that the Stockholm Convention teaches important lessons about effective environmental treaty development.

\section{The Emerging Problem of Persistent Organic Pollutants}

Scientists have been concerned about the effects of persistent organic pollutants for many years. After World War II, Americans became concerned over increased domestic pesticide use, the extremely toxic nature of these chemicals, and the scale on which they were being used. ${ }^{4}$ In 1962, Rachel Carson gave shape and substance to these apprehensions with Silent Spring, ${ }^{5}$ an early call to heed the effects of synthetic pesticides. Employing a style that would typify environmental advocacy for years to come, Carson told a story of a countryside silenced by invisible, poisonous pesticides, providing the impetus for much of the environmental legislation enacted in the 1970s. ${ }^{6}$ This influential story instilled awareness and galvanized public opinion in the United States ${ }^{7}$ through graphic

4. John S. Applegate et al., Regulation of Toxic Substances and Hazardous Wastes 527 (2000).

5. Rachel Carson, Silent Spring (1962).

6. John Harte et al., Toxics A to Z: A Guide to Everyday Pollution Hazards 114 (1991).

7. Silent Spring has been voted the most influential book of the past fifty years. Marilyn Goldstein, A Literature of Warning, NewsDAY, July 27, 1992, at 8. 
descriptions of DDT's effects upon birds of prey, ${ }^{8}$ and eventually led the federal government to ban domestic use of the pesticide. ${ }^{9}$

During this era, accumulation of toxic substances in the Great Lakes aquatic system and negative health impacts in wildlife species brought the subject home for many Americans who had been skeptical of Carson's strong warnings. ${ }^{10}$ Officials in the first Bush Administration soon came to understand the fundamental danger posed by the levels of toxic exposure experienced by Americans." Great Lakes residents began to believe that they were being exposed to higher levels of toxic chemicals than people in other regions of the country, as they witnessed the damage wrought by accumulation of toxic chemicals. ${ }^{12}$ Throughout this period, discoveries that other chemicals once considered safe-such as polychlorinated biphenyls (PCBs) and chlorofluorocarbons (CFCs)—could be deadly to humans prompted American policymakers to enact several statutes banning or severely restricting the use of these substances as well..$^{13}$

Pesticide poisonings in South and Central America put the international community on alert about synthetic chemicals, and raised the specter of concern

8. Richard L. Williamson et al., Gathering Danger: The Urgent Need to Regulate Toxic Substances That Can Bioaccumulate, 20 Ecology L.Q. 605, 640-41 (1993).

9. Id. at 640-41. In 1969, the U.S. Department of Agriculture proposed cancellation of certain uses of DDT. 34 Fed. Reg. 18,827 (1969). After acquiring jurisdiction, the newly formed Environmental Protection Agency (EPA) cancelled most of the remaining registered uses for DDT, and Administer Ruckelshaus affirmed this cancellation in 1972. 37 Fed. Reg. 13,369 (1972).

10. Peter L. Lallas, The Role of Process and Participation in the Development of Effective International Environmental Agreements: A Study of the Global Treaty on Persistent Organic Pollutants (POPS), 19 UCLA J. Envtl. L. \& Pol'y 83, 90 (2000).

11. See Gordon K. Durnil, The Making of a Conservative Environmentalist (1995). As a Bush appointee to the U.S.-Canada International Joint Committee for Water Quality, Durnil assessed scientific evidence of Great Lakes contamination and interviews with thousands of individuals and determined that toxic chemicals indeed posed a significant threat to human health, compiling his findings in a book: "consequences to humans and their children cannot even be predicted. However, the increased risks of cancer to the exposed adult and, more worrisome, the effects on the unborn progeny of the exposed, are frightening." Id. at 86.

12. Theo Colborn et al., Our Stolen Future: Are We Threatening Our Fertility, Intelligence, and Survival? - A Scientific Detective Story 15 (1996). As the authors recount, concern over the Great Lakes region escalated further in 1969 when the Cuyahoga River caught fire, Lake Erie was pronounced "dead," and scientists judged that other lakes were also seriously endangered. Id. at 13-14.

13. Lallas, supra note 10, at 90; see also, e.g., Toxic Substances Control Act (TSCA), 15 U.S.C.A. $\S 2605(\mathrm{e})(2000)$. 
over pesticides used in agriculture. ${ }^{14}$ In 1984, the release in Bhopal, India, of a cloud of deadly pesticide gas (methyl isocyanate) killed thousands, and inspired international appreciation for the dangers associated with pesticides. ${ }^{15}$

With the increase in international trade, appreciation of the dangers of pesticides became more acute in the United States because of the pesticide "circle of poison." 16 The circle of poison refers to the observed cycle whereby pesticides that have been banned domestically are exported to other countries and applied to agricultural export crops. ${ }^{17}$ Often the countries importing the pesticides are developing nations, where problems arise due to unsafe handling and storage practices, as well as improper labeling. ${ }^{18}$ When regulating countries, such as the United States, then import the pesticide-bearing crops, the circle is complete, and consumers in these developed countries risk exposure to the invisible poisons, despite domestic laws written to protect them. ${ }^{19}$ Thus, the circle of poison highlights the need for international controls on pesticides, POPs, and other toxic chemicals.

POPs are hazardous and potentially life-threatening organic compounds, whose designation comes from their chemical characteristics. POPs are difficult to break down, since they resist photolytic, chemical, and biological degradation. ${ }^{20}$ As a result, POPs persist in the environment, and would continue to pollute the earth for many years to come, even if releases were to cease

14. David Weir \& Mark Schapiro, Circle of Poison: Pesticides and People in a Hungry World 11-14 (1981) (citing Central American Institute of Investigation and Industrial Technology (ICAITI), An Environmental and Economic Study of the Consequences of Pesticide Use in Central American Cotton Production: Final Report, 97-98 (1977)). During the period from 1972 to 1975 , more than 14,000 poisonings and many deaths from pesticides were recorded on cotton plantations in Central America, due to indiscriminate use and application of pesticides, often while workers toiled in the field. Id.

15. Harte et AL., supra note 6, at 190.

16. See generally Weir \& Schapiro, supra note 14. See also Hilary French, Vanishing Borders: Protecting the Planet in the Age of Globalization, 76-81 (2000).

17. Richard W. Emory, Jr., Probing the Protections in the Rotterdam Convention on Prior Informed Consent, 11 Colo. J. Int'L Envtl. L. \& Pol'y 47 n.4 (2001); see also Circle of Poison: Impact of U.S. Pesticides on Third World Workers: Hearing Before the Senate Committee on Agriculture, Nutrition, and Forestry, 102d Cong. 1-2 (1991) (describing a specific example of litigation involving the DBCP).

18. See Lallas, supra note 10 , at 100.

19. For an extended discussion, see FreNCH, supra note 16, at 76-81.

20. Christina S. Chen, Comment, Persistent Organic Pollutants: Regime Formation and Norm Selection, 13 Conn. J. INT'L L. 119 (1998). 
immediately. ${ }^{21}$ POPs also accumulate in the fatty tissues of living beings, due to their persistence, low water solubility, and high lipid solubility. ${ }^{22}$ As a result, POPs tend to biomagnify in food systems, accumulating in high levels in organisms at the top of the food chain, rendering them the most susceptible to potential adverse health effects. ${ }^{23}$ Today, POPs are ubiquitous; scientists have found them in measurable levels in living organisms,${ }^{24}$ including in human blood and breast milk, across the globe. ${ }^{25}$ POPs' persistence and their volatility also allow them to move around the world, transported by both air and water currents. ${ }^{26}$ The "grasshopper effect," whereby POPs move in hopping fashion due to variations in climate and temperature, ${ }^{27}$ has allowed POPs to reach areas in the high

21. Michelle Allsopp et al., The Tip of the Iceberg: State of Knowledge on Persistent Organic Pollutants in Europe and the Arctic 2 (1999).

22. Id.; see also Final Report of the IFCS Ad Hoc Working Group on Persistent Organic Pollutants, Intergovernmental Forum on Chemical Safety (IFCS) 2 (1996), at http://irptc.unep.ch/pops/indxhtms/ manwgrp.html.

23. See Chen, supra note 20 , at 120 . "The terms bioaccumulation, bioconcentration, and biomagnification all denote processes that concentrate a chemical substance in living tissues" as it moves up the food chain. Williamson, et al, supra note 8, at 609. For more background on scientific findings related to POPs, see United Nations, ECE Convention on Long-Range Transboundary Air Pollution (LRTAP), Ad Hoc Preparatory Working Group on Persistent Organic Pollutants, Meeting Paper on Task VIII: Additional Information Concerning Significant Developments Since the Completion of the 1994 Report of the Former Task Force on Persistent Organic Pollutants (1995) [hereinafter LRTAP Working Group].

24. Kristin S. Schafer et al., Nowhere to Hide: Persistent Toxic Chemicals in the U.S. Food Supply, Pesticide Action Network North America/Commonweal 9 (2001).

25. See Center for Health and Environmental Justice \& Health Without Harm, A Comprehensive List of Studies of Human Contaminants (2000), at http:/www.ntec.org/superfund/contam.html.

26. L. Ritter et al., An Assessment Report on Persistent Organic Pollutants (1995), available at http:/ /irptc.unep.ch/pops (a joint undertaking of the Inter-Organization Programme on the Sound Management of Chemicals (IOMC), the International Programme on Chemical Safety (IPCS), and the Intergovernmental Forum on Chemical Safery (IFCS), assessing the "dirty dozen" POPs and consolidating existing information on the relevant chemistry and toxicology, transport and disposition, and availability and costs of substitutes to these substances).

27. Lallas, supra note 10, at 96; see also Arctic Pollution Issues: A State of the Arctic Environment Report, Arctic Monitoring and Assessment Project (AMAP) (1997), at http:/www.amap.no/ assess/soaer-cn [hereinafter AMAP Report]; ColborN ET AL., supra note 12, at 87-110 (describing the process by which PCBs and other POPs move through the global environment). See generally Frank Wania \& Donald Mackay, Tracking the Distribution of Persistent Organic Pollutants, 30 ENvtl. Sci. \& TECH. 390 (1996) (explaining that effective control of POPs requires an understanding of their migration processes). 
Arctic, far away from any industrial application. ${ }^{28}$ As a result, even indigenous peoples of the Arctic face exposure to these chemicals in amounts that exceed tolerable intake levels. ${ }^{29}$

The pervasiveness of POPs in the global environment would not be so troubling were it not for their danger to human and animal life and their persistence in living organisms. Nine of the twelve POPs identified by the U.N. Environmental Programme (UNEP) for regulation are pesticides, including aldrin, dieldrin, DDT, endrin, chlordane, hexachlorobenzene $(\mathrm{HCB}),{ }^{30} \mathrm{mirex}$, toxaphene, and heptachlor. ${ }^{31}$ Many of these substances are widely recognized as so dangerous that little debate is heard about the need to prohibit or virtually eliminate them. ${ }^{32}$ The two other categories of POPs, industrial chemicals and industrial byproducts, consist of PCBs and HCBs, and dioxins and furans, respectively. ${ }^{33}$ These chemicals are also known to be toxic to humans at extremely low levels. ${ }^{34}$ In general, the "dirty dozen" POPs are acutely or chronically toxic, or are classified as known or probable human carcinogens. ${ }^{35}$ POPs are also linked to the learning, developmental, and behavioral disabilities that afflict children. ${ }^{36}$

28. See generally AMAP Report, supra note 27 (reporting the discovery of POPs in the high Artic in levels that can only be explained by transport from lower latitudes).

29. Id., Executive Summary $\$ 3.3$.

30. Originally used as a fungicide for seed grain, HCB is produced during the manufacture of chlorinated solvents, other chlorinated compounds, and several pesticides; as such, it falls between the categories of POPs. Allsopp Et AL., supra note 21, at 3, Box 1.1.

31. Persistent Organic Pollutants: Socioeconomic Considerations for Global Action 2-3 (IFCS ed., 1996), available at http://irptc.unep.ch/pops/indxhtms/manpops2.html [hereinafter Socioeconomic Considerations for Global Action].

32. Don Mayer, The Precautionary Principle and International Efforts to Ban DDT, 9 S.C. ENVTL. L.J. 135, 144 (2002) (citing DURNIL, supra note 11, at 58).

33. Socioeconomic Considerations for Global Action, supra note 31 , at 3.

34. See Schafer et al., supra note 24, at 10. The EPA has called one form of dioxin the most potent synthetic carcinogen ever found. Center for Health and Environmental Justice, The American People's Dioxin Report: Technical Support Document (2000), at http:/www.mindfully.org/pesticide/ dioxin-report-cehj.htm.

35. See Anne Platt McGinn, Why Poison Ourselves? A Precautionary Approach to Synthetic Chemicals 8 (2000). See also Harte et al., supra note 6, at xii; Schafer et al., supra not 24, at 10, 23-24; IARC Monographs on the Evaluation of Carcinogenic Risks to Humans, Polychlorinated Dibenzo-para-dioxins and Polychlorinated Dibenzofurans (1997); WoMen's ENvironment AND Development Organization (WeDO), A Persistent Organic Pollutants Primer 2 (1998), available at http://www.wedo.org/ehealth/popsprimer.

36. See Schafer et al., supra note 24, at 23 (citing studies that link POPs to neurodevelopmental problems and reduced intellectual performance in both children and monkeys exposed to PCBs). 
The most important impact of POPs-one that has emerged only recently in studies and the popular press-may well be non-cancer risks associated with exposure. ${ }^{37}$ Rachel Carson's Silent Spring warned of these so-called endocrinedisrupting effects of DDT, which led to the rapid decline in bird populations in the 1960s. ${ }^{38}$ The authors of Our Stolen Future ${ }^{39}$ sounded a similar alarm with regard to endocrine disruption, exploring possible links between exposure to extraordinarily low levels of POPs and disruptions in animal and human hormone systems, including the male and female sex hormones responsible for fetal development. ${ }^{40}$ Endocrine disruption studies present evidence of reproductive and immune system damage ${ }^{4 l}$ occurring during pregnancy, when endocrinedisrupting chemicals mimic or block signals sent to a developing fetus to guide its development. ${ }^{42}$ Disruption during this stage is thought to lead to serious problems as the offspring develops, including, cancer, endometriosis, learning disorders, behavioral disorders, low sperm count, and genital malformations. ${ }^{43}$ Additionally, endocrine-disrupting chemicals have effects on developing fetae at different "developmental windows" and dosages, which makes estimating their effects extremely problematic. ${ }^{44}$ These chemicals also appear to have additive, synergistic effects that do not appear until the offspring reach puberty. ${ }^{45}$ Due to these factors, and the ability of POPs to bioaccumulate in fatty tissue and trans-

37. John S. Applegate ex AL., supra note 4, at 39-42. Traditionally, risk assessment, the process by which scientists and policymakers analyze and measure health effects from chemical exposure, has focused on cancerous effects of those chemicals. Lallas, supra note 10, at 94; see also COLBORN ET AL., supra note 12, at 19 ("For the past three decades, ['toxic chemicals'] have become almost synonymous with cancer not only in the public mind but in the minds of scientists and regulators as well....").

38. Schafer et al., supra note 24 , at 25.

39. Colborn et al., supra note 12.

40. Schafer et al., supra note 24 , at 24.

41. Lallas, supra note 10 , at 94 (citing numerous studies on endocrine disruption related to POPs); see also AMAP Report, supra note 27, ch. 6 (identifying numerous adverse effects in wildlife linked to POPs, including eggshell thinning and lowered reproductive capacity among birds of prey); The Royal Society of Chemistry, Report on Endocrine Diskupting Chemicals (EDCs) (2000).

42. Women's Environment and Development Organization (WEDO), The Dirty Dozen: POPs Designated for International Action 4 (2001), available at http://www.wedo.org/ehealth/ popsprimer2.htm.

43. Id.

44. Lallas, supra note 10 , at 94 .

45. Id. 
mit from mother to child through fetal development or breast milk, ${ }^{46}$ endocrine disruptions present significant potential dangers for human populations with extensive exposure to these pollutants. ${ }^{47}$ This fact is particularly troubling in light of findings that POPs are found around the globe ${ }^{48}$ in measurable amounts that may be sufficient to cause significant endocrine disruption. ${ }^{49}$

The research on endocrine disruption is still in its early stages, and there is still no scientific consensus about how endocrine disruption affects human health. ${ }^{50}$ Despite compelling evidence implicating chemical contamination in the disruption of certain fish and wildlife endocrine systems, "the relationship of human diseases of the endocrine system and exposure to environmental contaminants is poorly understood and scientifically controversial." ${ }^{11}$ This lack of consensus reflects both the relatively recent nature of the research on endocrine disruption and constraints involved in constructing experiments on human beings. Information on human effects is also limited due to scarcity of data on concentrations of contaminants in human embryos and the lack of multi-generational exposure studies that simulate ambient concentrations. ${ }^{52}$ Despite the lack of conclusive evidence about effects on human systems from chemical contamination, observed and welldocumented effects on wildlife species provide the incentive for prophylactic regulation that could prevent further exposure to these dangerous compounds.

Due in part to the advocacy of domestic environmental groups, developed countries have already banned or restricted several of the POPs discussed here. ${ }^{53}$ However, POPs are exported to non-regulating countries, where they are used for

46. Id. (citing AMAP Report, supra note 27; Colborn ET Al., supra note 12).

47. See generally Jane Houlihan et al., Environmental Working Group (EWG), Moms ... and POPs: Persistent Organic Pollutants in the Diets of Pregnant and Nursing WOMEN (2000).

48. See Schafer et al., supra note 24 at 9.

49. See id. at 24-25.

50. See Lallas, supra note 10, at 96. See generally AMAP Report, supra note 27; U.S. Environmental Protection Agency Endocrine Disruptor Screening Program Website, at http:/www.epa.gov/ scipoly/oscpendo/ [hereinafter Endocrine Disruptor Screening Program Website].

51. Endocrine Disruptor Screening Program Website, supra note 50; see also Colbonn ET AL., supra 12, at 13-15; Howard A. Bern et al., Chemically-Induced Alterations in Sexual Development: The Wildlife/Human Connection (The Wingspread Consensus Statement) (hereinafter Wingspread Statement], in Colborn ET AL., supra note 12, at 252-60; AMAP Report, supra note 27, at ch. 12.

52. See Wingspread Statement, supra note 51, at 255-58.

53. McGinn, supra note 3, at 75; see also Roger Thurow, As a Tropical Scourge Makes a Comeback. So, Too, Does DDT, WAll Sr. J., July 26, 2001, at A1 (focusing on the DDT-malaria issue in South Africa). 
agricultural and related pest-control applications. ${ }^{54}$ Use of the pesticide POPs in agriculture leads to poisoning among farm workers, who are often uninformed about the dangers posed by these chemicals. ${ }^{55}$ Results from this exposure can include sterility, ${ }^{56}$ cancer, miscarriages, deformed babies, and even death for farm workers. ${ }^{57}$ POPs are especially devastating in the developing world, where countries often lack the capacity to regulate POPs domestically. ${ }^{58}$ Worse still, pesticide POPs have been included in aid packages to developing countries, despite known or suspected negative health effects. ${ }^{59}$ Writers describing exports of hazardous chemicals have labeled this practice "environmental racism,"-the behavior by which some humans are treated worse than others, and forced to live under environmental conditions that the more powerful would never accept. ${ }^{60}$ The extreme poverty of developing nations creates a dynamic in which the states accept dangerous chemicals—either for disposal or deposit onto export crops—because they

54. Robin L. Cowling, PIC, POPs and the MAI Apocalypse: Our Environmental Future as a Function of Investors' Rights and Chemical Management Initiatives, 21 Hous. J. INT'L L. 231, 265 (1999); see also James H. Colopy, Poisoning the Developing World: The Exportation of Unregistered and Severely Restricted Pesticides from the United States, 13 UCLA J. ENvTL. L. \& PoL'y 167, 173 (1994). Pesticide POPs are routinely sold to developing countries by U.S. multinational corporations, despite domestic regulation in the exporting country based on the chemicals' potential danger to humans. See generally Weir \& SCHAPIRo, supra note 14.

55. Cowling, supra note 54, at 235; see also WeIR \& SchapIRo, supra note 14, at 10-17 (describing effects of the global pesticide trade in the early 1980s, particularly on agricultural workers in developing nations).

56. See Costa Rica: The Price of Bananas, The Economist, Mar. 12, 1994, at 48.

57. WeIR \& SCHAPIro, supra note 14, at 11-13. Modern estimates of the number of pesticide poisonings each year reach 25 million, most of which occur in the developing world, according to the U.S.-based Global Environment Facility (GEF). Moussa Awuonda, Pesticide Poisoning Pose Concern to Third World, Afr. Church INFo. Service, June 11, 2001, at http://allafrica.com/stories.

58. WeIR \& Schapiro, supra note 14, at 15-16. According to the authors, illiteracy and the lack of knowledge about dangerous chemicals leads to poisonings on a massive scale, most of which could have been avoided. See also Faith Halter, Regulating Information Exchange and International Trade in Pesticides and Other Toxic Substances to Meet the Needs of Developing Countries, 12 Colum. J. ENvTL. L. 1, 4-5 (1987); Colopy, supra note 54, at 173-79.

59. Weir \& Schapiro, supra note 14, at 48-64; see also Awounda, supra note 57.

60. The "racism" enters the equation because the exporters of hazardous chemicals tend to be Caucasian, while the importing countries are generally African or South/Central American. See Faces of Environmental Racism: Confronting Issues of Global Justice, at ix-xiii (Laura Westra \& Peter S. Wenz eds., 1995); see also Rozelia S. Park, An Examination of International Environmental Racism Through the Lens of Transboundary Movement of Hazardous Wastes, 5 IND. J. GLObal Legal Stud. 659 (1998); Hugh J. Marbury, Note, Hazardous Waste Exportation: The Global Manifestation of Environmental Racism, 28 VAND. J. Transnat'L L. 251 (1995). 
have no choice. ${ }^{61}$ Indeed, many argue that this problem is unlikely to improve as long as cash crops are required to pay foreign debt. ${ }^{62}$

\section{Evolution of Global Concern over POPs}

As indicated above, many POPs were banned in the United States and nations of Western Europe after initial concern over their effects surfaced in the $1970 \mathrm{~s} .{ }^{63}$ Regional bans, including a series of initiatives in the North Sea and other regions of Europe, among the countries of the European Union represent other attempts to regulate POPs on a broader scale. ${ }^{64}$ Regional bans were also implemented in North America as part of a series of initiatives to take action against toxic chemicals in the Great Lakes ecosystems. ${ }^{65}$ In 1995, Canada, Mexico, and the United States agreed to a Resolution on the Sound Management of Chemicals under the North American Agreement on Environmental Cooperation, which called for the development of action plans to add ress problems posed by persistent toxic substances. ${ }^{66}$ Despite the progress they represent, however, regional bans are limited in their potential effectiveness against chemicals with the properties of POPs. ${ }^{67}$ One reason is that developing countries tend not to become parties to these regional bans, which means that the chemicals may still be imported into those countries without prohibition. Further, through evidence of long-range

\footnotetext{
61. See Cowling, supra note 54, at 240.

62. Id, at 236.

63. See Lallas, supra note 10 , at 91 ; see also Chen, supra note 20 , at 121.

64. See The Convention for the Protection of the Marine Environment of the North East Atlantic (the OSPAR Convention), Sept. 22, 1992, available at http://www.ospar.org/eng/html/welcome.html; see also 1979 Convention on Long-Range Transboundary Air Pollution and its 1998 Protocols on POPs and heavy metals, United Nations Economic Commission for Europe (ECE), U.N. Salves No. E.99.II.E.21 (June 1998), at http://www.unece.org/env/rtap/lrtap_hl.htm. See generally John Buccini, POPs: Recent Developments in the Intergovernmental Forum on Chemical Safety (from the proceedings of the UNEP Cartagena workshop), at http://irptc.unep.ch/pops/ pops_inc/proceedings/cartagena/buccinil.html.

65. See U.S.-Canada Bi-national Strategy for the Virtual Elimination of Toxic Substances, April 1997, at http://www.epa.gov/glnpo/p2/bns.html; see also Peter Lallas, Canada-United States Binational Strategy for the Virtual Elimination of Toxic Substances in the Great Lakes, 32 INT'L LAw 515 (1998).

66. See North American Commission for Environmental Cooperation, at http:/www.cec.org/ programs_projects/pollutants_health/index.cfm?varlan=english (describing the agreement's chemicals program).

67. See Lallas, supra note 10, at 101-05. See generally Schafer et al., supra note 24 (discussing weaknesses of the OSPAR Convention as a means of addressing the POPs problem).
} 
transport of POPs, in conjunction with information about their persistence and toxicity, policymakers and societies have become more aware of the transboundary nature of toxic problems, and the resulting implications for global environmental systems. ${ }^{68}$ Thus, increased understanding of the dangers of POPs, and the realization that they do not respect national or continental boundaries, contributed to the consensus that international regulation was necessary.

\section{A. International Action on POPs}

Concerted international action on the problem of POPs began in the 1990s. The 1992 Rio Earth Summit marked a step forward in international cooperation to reduce the dangers of POPs and other toxic chemicals. ${ }^{69}$ In Rio, members of the international community joined together to develop a set of principles on the environment and development, along with an action plan entitled Agenda $21 .^{70}$ Chapter 19 of Agenda 21 targets POPs, calling for actions that include "phasing out or banning [toxic chemicals] that pose an unreasonable and otherwise unmanageable risk to the environment or human health and those that are toxic, persistent and bio-accumulative...." ${ }^{71}$ Agenda 21 also called for further action to promote prior informed consent, which foreshadowed the negotiation of a global treaty to regulate information on international shipments of hazardous substances. ${ }^{72}$

The concept of Prior Informed Consent (PIC) grew out of international concern about the growing chemical trade. PIC reflects the notion that international shipment of a pesticide that is banned or severely restricted in order to protect human health or the environment should not proceed without the agreement of a competent national authority in the importing country. ${ }^{73}$ In 1985 , the

68. See Edith Brown Weiss \& Szasz Magraw, International Environmental Law and Policy 528-31 (1998); see also Hunter et al., International. Environmental Law and Policy (1998) (identifying pollution from toxic chemicals and hazardous wastes as one of the four basic global environmental issues).

69. See Lallas, supra note 10, at 103.

70. See, e.g., Hunter et Al., supra note 68 (discussing the Rio Conference extensively).

71. Agenda 21, \$2, para. 19.49, June 14, 1992, at http:/www.un.org/esa/sustdev/ agenda2 1 text.htm.

72. See Rotterdam Convention on Prior Informed Consent Procedure for Certain Hazardous Chemicals and Pesticides in International Trade (Rotterdam PIC Convention), opened for signature Sept. 10, 1998, at http://www.pic.int//en/viewpage.asp? id = 104.

73. Cowling, supra note 54, at 242-43; see also Colopy, supra note 54, at 198. 
U.N. Food and Agriculture Organization (FAO) developed an International Code to guide this process. ${ }^{74}$ The International PIC Code, along with the 1987 UNEP guidelines, was designed to increase access to information regarding hazardous chemicals for all states. ${ }^{75}$ These documents, and the international concern that inspired them, led eighty nations to negotiate and sign the Rotterdam PIC Convention in September 1998. ${ }^{76}$ The PIC Convention is premised upon the goal of promoting shared responsibility between importers and exporters over the health and environmental risks associated with hazardous substances. ${ }^{77}$ One disadvantage of the International PIC Code is that it is voluntary, and does not contain any mechanisms to ensure compliance; rather, it relies upon the collaborative efforts of actors in international trade to guarantee its success. ${ }^{78}$ Another major disadvantage of the PIC procedure generally is that the system does not develop the regulatory expertise of the developing countries; instead, it requires officials from such countries to "sign off" on shipments about which they really know very little. ${ }^{79}$

Despite its limitations, however, the Rotterdam PIC Convention makes an important contribution to global chemicals management by drawing attention to those substances that cause the greatest harm, disseminating information about the harms caused by these substances, and facilitating national decisionmaking on chemical imports. ${ }^{80}$

Along with the notion of PIC, the dangers of POPs have emerged in the years since the Rio Summit as a top priority in the international community. ${ }^{81}$ Momen-

74. International Code of Conduct on the Distribution and Use of Pesticides, F.A.O. Res. 10/85, U.N. F.A.O., 25th Sess. (1989), reprinted in Basic Documents of International Environmental Law 173 (Stanley P. Johnson \& Gunther Handl, eds, 1989) [hereinafter International PIC Code]; see also Cowling, supra note 54, at 241-43.

75. Cowling, supra note 54, at 241.

76. For a careful analysis of the PIC Convention and likely effectiveness, see generally Emory, stupra note 17 (probing "substantial" weaknesses of the Convention and offering suggestions for revising it).

77. See U.N. Environment Programme (UNEP), PIC: Prior Informed Consent for Certain Hazardous Chemicals in International Trade, at http://irptc.unep.ch/pic.

78. See International PIC Code, supra note 74, at 186; see also Colopy, supra note 54, at 245.

79. Colopy, supra note 54, at 197; see also Gretta Goldenman \& Sarojini Rengam, Problem Pesticides, Pesticide Problems: A Citizens' Action Guide to the International Code of Conduct on the Distribution and Use of Pesticides 3 (2d ed. 1988).

80. World Wildlife Fund (WWF), Advancing International Controls on Toxic Chemicals 2 (Apr. 2001), at http://www.worldwildlife.org/toxics/pubres/treatyratif.pdf.

81. Lallas, supra note 10 , at 105. 
tum to confront the dangers from POPs grew with the creation of the Intergovernmental Forum on Chemical Safety (IFCS) in 1994 in Stockholm, Sweden. ${ }^{82}$ A year later, the UNEP conference in Washington on land-based sources of marine pollution called for international action to reduce or eliminate POPs. ${ }^{83}$

UNEP led the way toward creating the first global treaty on POPs, calling for an international assessment process for POPs in $1995 .^{84}$ In 1996, the Intergovernmental Forum on Chemical Safety (IFCS) held a weeklong meeting in Manila at which technical experts presented recommendations for developing a legally binding global treaty on POPs. ${ }^{85}$ Then, in February 1997, the IFCS presented its findings to the international community, gathered at a meeting of the UNEP Governing Council. This led to a legal mandate to negotiate a binding multinational treaty, focusing exclusively on the initial twelve POPs for immediate action, ${ }^{86}$ and agreeing to finalize the treaty by the year $2000 .{ }^{87}$ In early 1997 , UNEP adopted Decision 19/13, recommending that the Governing Council establish an Intergovernmental Negotiating Committee (INC) to negotiate a glo-

82. See IFCS Website, at http://www.who.int/ifcs. The IFCS, which served as a forum for highlevel international environmental policymakers, was to play a critical role in developing a mandate for negotiating the POPs convention. Lallas, supra note 10, at 108.

83. Washington Conference on Land-Based Sources of Marine Pollution, Oct.-Nov. 1995 (adopting a "Global Program of Action for the Protection of the Marine Environment from Land-Based Activities," which called for international action to address POPs); see also UNEP Conference on Protection of the Marin Environmental from Land-Based Activities, Washington, 1995, at http://www.nmfs.noaa.gov/prot_res/pr/fpweb/icri/text/2115b.htm.

84. Cowling, supra note 54, at 266 (discussing the adoption of Decision 18/32, in which the UNEP Governing Council invited the Inter-Organization Programme for the Sound Management of Chemicals (IOMC), the International Programme on Chemical Safety (IPCS), and the IFCS to assess the "dirty dozen" POPs and present UNEP with regulatory recommendations); see also Decision 18/32 of the UNEP Governing Council: Persistent Organic Pollutants, G.C. Dec. 18/32, U.N. EP, 18th Sess., 9th mtg., U.N. Doc. UNEP/GC.18/32 (1995), available at http://irptc.unep.ch/ pops/indxhtms/gcl 832 en.html.

85. See Cheryl Hogue, U.N. Urged to Negotiate Treaty on Persistent Organic Pollutants, 19 INT'L ENv't Rep. 808 (1996).

86. Cowling, supra note 54, at 267. In Decision 19/13C, the UNEP Governing Council concluded that "international action is required to reduce the risks . . f from the release of the twelve specified POPs." G.C. Dec. 19/13C, U.N. EP, 19th Sess., 8th mtg., U.N. Doc. UNEP/GC.19/13C (1997) (emphasis added), available at http://irptc.unep.ch/pops/gcpops_e.html [hereinafter Decision 19/13C]. Indeed, the question about what chemicals to add, when to add them, and how to do so would plague delegates throughout the negotiations.

87. See Decision 19/13C, supra note 86; see also Michael Roberts, UNEP Aims for POPs Treaty by 2000, Chemical Wr., Feb. 26, 1997, at 49. 
bal POPs instrument. ${ }^{88}$ From late 1997 to 2000, UNEP INC sessions and Awareness Workshops brought together experts and policymaking officials to discuss scientific and technical issues raised by POPs and to negotiate the treaty. ${ }^{89}$ It was through these vehicles that the primary negotiations for the POPs occurred, and their story is the story of the POPs experience.

\section{B. Early POPs Issues}

From the outset, POPs presented a number of substantive issues that negotiators of a global treaty had to resolve. The parties first had to identify guiding principles for the negotiations. Perhaps the most important of these principles was how to present the need for caution in response to the significant uncertainty surrounding POPs and their effects, and whether to refer to a "precautionary principle" explicitly in the agreement. ${ }^{90}$ Another important issue early on was how quickly to eliminate the use of POPs with continuing beneficial uses. $^{91}$ While an immediate ban on many of the POPs would be the most extreme-and likely the most environmentally beneficial control strategynegotiators recognized the need to develop viable alternatives to the chemicals that could be made widely available. ${ }^{92}$ Another important early issue facing negotiators was how to ensure the careful and efficient management of existing stocks of POPs to ensure that they would not be traded illegally or misused. ${ }^{93}$

88. Decision 19/13C, supra note 86; Lallas, supra note 10, at 109.

89. See Lallas, supra note 10, at 111-18.

90. See discussion infra text accompanying notes 183-88, 191-214; see also Lallas, supra note 10, at $113 \mathrm{n} .118$ (asserting that the precautionary principle issue has become one of the most contentious in international environmental policy). This concept is encapsulated in Principle 15 of The Rio Declaration, and has been included in many multilateral environmental agreements since then. See, e.g., Rio Declaration on Environment and Development, June 14, 1992, princ. 15, 31 I.L.M. 814, 816 (1992), available at http:// www.unep.org/documents/default.asp?documentid=78\&articleid $=1163$ [hereinafter Rio Declaration], Patricia W. Birnie \& Alan E. Boyle, International Law and the Environment 95-98, 455 (1992). For further discussion of this issue, see HunTER ET AL., supra note 68.

91. UNEP Decision $19 / 13 \mathrm{C}(\mathrm{b})$ recommends the use of transition periods, with "phased implementation of various proposed actions." See Decision 19/13C, supra note 86 . Transition periods are particularly important with respect to certain industrial chemicals, including PCBs, which remain in wide use.

92. Chen, supra note 20, at 134-35 (discussing bans and restrictions of POPs). The debate over DDT, discussed below, was particularly strong with regard to this point.

93. In the wake of the Montreal Protocol, a black market in CFCs has developed which is thought to be second in significance only to the international trade in illegal narcotics. See Elizabeth R. 
The participation of developing countries in the negotiation and implementation of the POPs regime arose as another fundamental issue in the early part of the negotiation process. Initial questions concerned whether the "short list" of POPs identified for regulation even reflected the priorities of governments of the developing world, whose greatest concern centered on other substances with greater acute toxicity to workers, but insufficient persistence to be considered POPs. ${ }^{94}$ Deeper questions involved how to address the special needs of developing countries in implementing global environmental treaties, and how to incorporate these perspectives into the developing POPs regime. ${ }^{95}$ From the outset, it was clear to policymakers and observers alike that financial and technical assistance would have to be provided to developing countries to enable the countries to find alternatives and re-tool their manufacturing facilities. ${ }^{96}$ Structuring participation by developing countries throughout the POPs regime negotiation process also presented a formidable obstacle to negotiating an effective treaty. The way that negotiators were able to overcome these obstacles and craft a treaty regime that is likely to be successful at reducing the dangers from global POPs yields many lessons, both for the immediate POPs problem and for future international environmental agreements.

\section{Confronting Tensions in International Environmental Law}

Prior to the first multinational environmental conference in Stockholm in 1972, many developing countries did not accept the necessity of global cooperation to protect the environment. ${ }^{97}$ During the Stockholm Convention, many unindustrialized countries of the global South suspected that the wealthy nations

DeSombre, The Experience of the Montreal Protocol: Particularly Remarkable, and Remarkably Particular, 19 UCLA J. Envtr. L. \& Pol'y 49, 62-69 (2000) (discussing the danger of a black market in CFCs but concluding that it does not pose a long-term threat to the health of the Protocol system); see also Emory, supra note 17 at 53 (discussing the "huge challenges" these illegal CFC imports present to the operation of effective domestic or international environmental protection programs).

94. Lallas, supra nore 10 , at 112.

95. The concept of "common but differentiated responsibilities" for developing countries implementing international environmental agreements was developed as part of the Rio Declaration. Rio Declaration, supra note 90 , princ. 7.

96. Cowling, supra note 54, at 272-73 (asserting that a worldwide ban was needed for POPs and making its success contingent upon the provision of "extensive support to the developing world").

97. See Alexandre Kiss \& Dinah Shelton, International Environmental Law 624 (2d ed. 2000) (asserting that environmental problems were considered "predominantly an ailment of rich, 
of the North subordinated foreign economic development to environmental protection, "considering the former less urgent than pollution and nature protection." 98 "These developing countries "feared that funds previously dedicated to development would be diverted to fight environmental deterioration," resulting in a net loss of funds set aside for the South. ${ }^{99}$ In addition, developing countries expressed concerns that environmental provisions could be used by industrialized states to impose restrictions on exports from the South, effectively barring access to worldwide markets. ${ }^{100}$

Prior to the 1972 Convention, states in the global South also generally rejected the notion that environmental resources are global assets, subject to global protection. ${ }^{101}$ The idea that these resources constitute common heritage is considered hypocritical by developing countries who have witnessed the manner in which industrialized nations in the North are depleting their own natural resources, often more quickly than resources are being depleted in the developing world. ${ }^{102}$ Finally, states in the South fear that environmental protection, especially of scarce natural resources, is an "unaffordable luxury" that the industrialized North is trying to convince them to purchase. ${ }^{103}$

From these first manifestations to the present, international environmental law has been marked by tension between the abstract environmental concerns of

industrialized countries"); see also Ved P. NANda, International Environmental Law \& Policy 13 (1994) (describing less-developed countries' view that environmental protection was the "rich men's problem, [the] rich men's solution") (quoting Elizabeth P. Barratt-Brown, Building A Monitoring and Compliance Regime Under the Montreal Protocol, 16 YALE J. INT'L L. 519,534 (1991)).

98. See Kiss \& Shelton, supra note 97, at 624; see also NANDA, supra note 97, at 13.

99. Kiss \& Shelton, supra note 97, at 624; see also NANda, supra note 97, at 13; Bing Ling, Developing Countries and Ozone Layer Protection: 1ssues, Principles and Implications, 6 TuL. EnvtL. L.J. 91, 99 (1992).

100. See NANDA, supra note 97 , at 13.

101. See id. ("The assertion that resources within the territory of a sovereign state now belong to all of humanity, and that that state cannot freely exploit those resources, is particularly unpopular in former colonies.") (citing Ranee K.L. Panjabi, The South and the Earth Summit: The Development/Environment Dichotomy, 11 Dick. J. INT'L L. 77, 98-99 (1992)).

102. See $\mathrm{N}_{\mathrm{ANDA}}$, supra note 97 , at 13 (citing arguments by developing countries that the Pacific Northwestern United States' timber resources have been depleted far more extensively by clearcutting than the well-publicized destruction of the Brazilian rain forests that incite environmentalists' ire); see also Nassau A. Adams, Worlds Apart: The North-South Divide and the InterNational System 204 (1993).

103. NANDA, supra note 97 , at 13. 
the North and the specific development needs of the South. ${ }^{104}$ In an attempt to reconcile the competing global interests over environmental issues, negotiators at the 1972 Stockholm Convention coined the term "sustainable development," which has proved to be as ambiguous as the problem that inspired it. ${ }^{105}$ Governments of developing countries have been suspicious of this twist in the environmental debate-South as co-conspirator in harm to the global environmentand have expressed their ire at constraints implicit in the concept of sustainable development. ${ }^{106}$ In this way, global environmental debates are marked by tension between rich and poor, developed and undeveloped ${ }^{107}$ - tension mediated by the illusory notion of sustainable development. ${ }^{108}$

This friction is often borne out in multilateral environmental agreements (MEAs). Despite the fact that environmental regimes can and do generate broad participation in some instances, developing countries often characterize these treaties, and the globalizing forces that bring them about, as a new form of colonialism. ${ }^{109}$ Thus, environmental treaties are often viewed as the means through

104. See generally KIss \& SHelton, supra note 97, at 623-28 (describing the history of integrating developing countries into the process of international environmental law).

105. See A. Dan Tarlock, Ideas Without Institutions: The Paradox of Sustainable Development, 9 Ind. J. Global Legal Stud. 35, 39 (2001); see also Birnie \& Boyle, supra note 90, at 122-24 (highlighting the progressive argument that sustainable development is the central concept in international environmental policy, but noting the lack of any comparable consensus about the concept); Lynton Keith Caldwell, International Environmental Policy: From the Twentieth to the Twenty-First Century 9 (3d. ed 1996) (asserting that, despite its shortcomings, the sustainable development movement could strengthen international environmental policy and action by integrating ecological and economic theory in the concept of natural economics). See generally Kiss \& SHELTON, supra note 97, at 248-49 (providing background on the concept and an original definition of the phrase).

106. See Adams, supra note 102, at 204-07. Countries were especially incensed at calls by Northern environmentalists to halt land-clearing or other commercial exploitation of their lands to save the environment, while rich countries continued their extravagant burning of fossil fuels and overloaded the environment with noxious wastes generated by their excessive consumption habits. Id. at 204.

107. See id. at 206.

108. See John S. Applegate \& Alfred C. Aman, Jr., Introduction: Syncopated Sustainable Development, 9 Ind. J. Global Legal Stud. 1, 2, 11 (2001) (discussing "soft" and "hard" versions of sustainable development, and concluding that analysis of the tension over global resource allocation issues "end[s] in questions" rather than answers).

109. See Raymond William Baker, Egypt in the Space and Time of Globalism, in Globalization: Policies, Challences, and Responses 243-56 (Shereen T. Ismael ed., 1999); see also Danielle S. Petito, Note, Sovereignty and Globalization: Fallacies, Truth, and Perception, 17 N.Y.L. ScH. J. Hum. 
which rich Northern countries attempt to export their eco-consciousness to developing countries.

In many treaty contexts, this division can lead to insurmountable obstacles to negotiating treaty language, and indeed can prevent countries from reaching any consensus at all. The Basel Convention, which attempts to regulate the international movement of hazardous wastes, is an example of treaty negotiations that have been significantly hampered by the North-South divide. ${ }^{110}$ During the drafting of the documents that would become the Basel Convention in early 1989, delegates disagreed over numerous issues, including the question of prior informed consent (PIC) and even the definition of hazardous waste. ${ }^{11}$ More basic, however, was the Basel Convention's failure to ban the exportation of hazardous wastes. Instead of an outright ban, the Convention attempts to regulate the exportation and handling of hazardous waste through a set of integrated international and national standards. ${ }^{112}$

The regulation approach to managing hazardous waste imports and exports was rejected by numerous African states in particular, which view hazardous waste exportation to Africa as a crime against African people. ${ }^{113}$ Due to the lack of technical expertise and administrative capabilities of many African nations, these states are particularly susceptible to illegal dumping, a phenomenon all too com-

RTs. 1139 (2001) (arguing that globalization erodes sovereignty); Steven Mark, Harmonization or Homogenization?: The Globalization of Law and Legal Ethics: An Australian Viewpoint, 34 VAND. J. TransNat'L L. 1173 (2001) (arguing that globalization generally can lead to homogenization).

110. For interesting perspectives on this troubled regime, compare Daniel Jaffe, Note and Comment, The International Effort to Control the Transboundary Movement of Hazardous Waste: The Basel and Bamako Conventions, 2 ILSA J. INr'L \& Comp. L. 123 (1995) (detailing the UNEP's largely unsuccessful attempt to regulate the hazardous waste trade), with William N. Doyle, Comment, United States Implementation of the Basel Convention: Time Keeps Ticking, Ticking Away, 9 Temp. INT'L \& Comp. L.J. 141, 160 (1995) (concluding that "the Basel Convention represents an important, much needed step in the international effort to control the international waste trade"). For an interesting perspective on the problems of transboundary pollution generally, see Thomas W. Merrill, Golden Rules for Transboundary Pollution, 46 Duke L.J. 931, 988 (1997) (concluding that "effective regimes of collective action regulating transboundary pollution are not very likely to emerge" and that regulation of transboundary pollution is likely to come about, if at all, through evolution of other types of institutions).

111. See Jaffe, supra note 110, at 126-27.

112. Id. at 127 (citing David P. Hackett, An Assessment of the Basel Convention on the Control of Transboundary Movements of Hazardous Wastes and Their Disposal, 5 AM. U. J. INT'L L. \& POL'Y 291 (1990)); see also Doyle, supra note 110, at 143.

113. See Jaffe, supra note 110 , at 130 (citing C. Russell H. Shearer, Comparative Analysis of the Basel and Bamako Conventions on Hazardous Waste, 23 EnvtL. L. 142, 149 (1993)). 
mon in Africa. ${ }^{114}$ In response to widespread dumping and concerns that "business as usual" would not be abated by the Basel Convention, the Organization of African Unity (OAU) adopted the Bamako Convention, with the intention of banning all importation of hazardous waste into Africa. ${ }^{115}$ Perhaps the most significant feature of the Bamako Convention was its complete ban on imports of hazardous wastes from non- parties ${ }^{116}$ (i.e. non-African states), which had been the most contentious issue in the ratification of the Basel Convention. While the dispute over whether or not to ban the export of hazardous wastes from industrialized countries to Africa did not prevent the OAU states from sending delegates to, and signing the final text of, the Basel Convention, ${ }^{117}$ it remains the fundamental difference between the two Conventions. This difference, in conjunction with the widely divergent definitions of hazardous waste to which countries continue to subscribe, will likely prevent either of the hazardous waste conventions from being effective international environmental agreements. ${ }^{118}$

Perhaps an even better example of the roadblocks that economic and cultural divides pose to multilateral environmental agreements is the Kyoto Protocol, ${ }^{119}$ which attempts to address the problem of global warming by setting specific targets and timetables for reducing overall global emissions of green-

114. See id. at 130.

115. The Bamako Convention on the Ban of the Import into Africa and the Control of Transboundary Movement and Management of Hazardous Wastes Within Africa, Jan. 29, 1991, at http// www.jus.uio.no/lm/hazardous.waste.ban.afrian.import.bamako.convention.1991/index.html [hereinafter Bamako Convention].

116. See Jaffe, supra note 110 , at 132 .

117. See id. at 131 .

118. Id. at 133. However, parties to the Basel negotiations have adopted, but not yet ratified, the Basel Ban Amendment. The Basel Ban Amendment "prohibits the export, for any reason, of hazardous wastes from member states of the OECD and Liechtenstein to all other countries." See WWF, supra note 80, at 3; Basel Convention on the Control of Transboundary Movements of Hazardous Wastes and Their Disposal, 1995 Ban Amendment, Sept. 22, 1995, at http:// www.unep.ch/basel/pub/baselban.html [hereinafter 1995 Ban Amendment]. To become a binding part of the Basel regime, this Amendment will need to be ratified, along with the Convention, by the parties to the original Basel Convention. 1995 Ban Amendment, supra. If it wins the support of the Basel parties, the Basel Ban Amendment is likely to greatly strengthen a regime plagued with division, and result in a viable global system of hazardous waste regulation.

119. Conference of the Parties to the Framework Convention on Climate Change: Kyoto Protocol, Dec. 10, 1997, reprinted in 37 I.L.M. 22 (1998) [hereinafter Kyoto Protocol]. 
house gases (GHGs). ${ }^{120}$ Despite concerted efforts and extended negotiations among participating parties, no firm targets were included, and the regime has been commonly considered a failure. ${ }^{121}$ This perceived lack of success is due in large part to the regime's failure to secure the participation of the developing countries China, India, Brazil, and Indonesia, and the resulting failure of domestic ratification in the United States. ${ }^{122}$ However, with the ratification of the Protocol by Poland on August 8, 2002, and the European Union's focus on securing the rest of the ratifications, the regime will likely enter into implementation soon, albeit without the participation of several key players. ${ }^{123}$

In the POPs context, some negotiations between members of the Intergovernmental Negotiating Committee (INC) illustrated North-South friction, at least on the issue of elimination of DDT. ${ }^{124}$ This issue presents the choice between strict regulation or ban (when feasible) on the one hand, and elimination without qualifications on the other. ${ }^{125}$ Another divisive issue dealt with funding commitments to the developing world, with parties voicing various institutional, administrative, and oversight concerns. ${ }^{126}$ Despite often-daunting divisions, the story of the sessions illustrates how extensive participation from the world health and environmental communities was able to create an atmosphere in which issues could be resolved and significant progress achieved in the regulation of POPs.

120. See Ved P. Nanda, The Kyoto Protocol on Climate Change and the Challenges to Its Implementation: A Commentary, 10 Colo. J. Int'L Envtl. L. \& PoL'Y 319, 321 (1999).

121. See id. at 321-22 (discussing the "serious questions" that have arisen about the implementation of the goals of the Kyoto Protocol, and its bleak prospects for addressing global climate).

122. Instead of signing the Kyoto Protocol, which it believes would damage the domestic economy, the second Bush Administration intends to implement its Clear Skies Initiative, part of a set of voluntary reductions in greenhouse gas emissions. See The U.S. Alternative to the Kyoto Protocol, Platts Global Energy, at http://www.platts.com/features/kyotoprotocol/usalternative.shtml (last visited Feb. 13, 2003). The European Union's reaction to this move by the Bush Administration was to push ahead on the Kyoto Protocol, accusing the United States of backing out of commitments made during the U.N. Framework Convention on Climate Change (UNFCCC). Id.

123. See WWF, WWF Welcomes the Polish Ratification of the Kyoto Climate Treaty, Aug. 9, 2002, at http://www.panda.org/about_wwf/what_we_do/climate_change/news/news.cfm? unewsid=2640. With Poland's participation, 74 countries accounting for only $36 \%$ of the world's GHG emissions will be parties to the treaty. Id.

124. As the discussion below indicates, however, the issue of elimination divided negotiators from different countries more generally into patterns that cannot be described as North-South.

125. See Lallas, supra note 10 , at 99 (claiming that this tension has characterized international work on POPs).

126. See infra notes $215-19$ and accompanying text. 


\section{A. Addressing Tension Through Public Participation}

UNEP and state parties negotiating the POPs convention sought to address potential tensions by including as many perspectives as possible in the negotiations. One important way in which this was done was through the inclusion of NGOs as observers of the negotiation process. ${ }^{127}$ The POPs INC Rules of Procedure created roles for NGOs to take in the negotiations, and many groups took advantage of these opportunities, participating in formal meetings and organizing related events. ${ }^{128}$ Prior to the first INC session in Montreal in July 1988, a small group of NGOs combined to form the International POPs Elimination Network (IPEN), dedicated to a number of common positions with respect to POPs. Made up of international environmental and public health NGOs, IPEN was created to provide a forum for developing country NGOs to participate in the Stockholm POPs negotiations. ${ }^{129}$ In fact, in addition to many large NGOs from the North, including Greenpeace, World Wildlife Fund, and others, the vast majority of IPEN member groups hail from developing countries. ${ }^{130}$ IPEN member groups represented a broad spectrum of citizens' groups dealing with a range of issues related to environmental and public health. ${ }^{131}$ These NGOs made their positions extremely clear during the INC sessions and worked to educate their own country representatives about the important public health and environmental concerns POPs pose to different populations. ${ }^{132}$ These groups

\footnotetext{
127. Normally, negotiations for Multilateral Environmental Agreements (MEAs) are carried on in relative obscurity with very little NGO interaction; in the POPs context, NGOs were active in various roles throughout the negotiating process, by, e.g., generating awareness, providing additional perspectives and expertise, and helping to highlight problems among negotiators. See Lallas, supra note 10 , at $118-35$.

128. See id. at 118-20.

129. For more information on IPEN and its work during and since the negotiations, see IPEN Website, at http://www.ipen.org.

130. See id.

131. See id.

132. See id.
} 
also intervened in the negotiating process, held meetings of participating organizations, and even engaged in demonstrations. ${ }^{133}$

From the outset, member groups in IPEN organized around a set of principles that developed into their Elimination Platform. ${ }^{134}$ The platform articulated IPEN's purpose: to facilitate a systematic, global program of action in which all countries would participate to eliminate POPs and their release into the environment. ${ }^{135}$ Because of member groups' efforts, IPEN helped define the terms of the debate over POPs, arguing that the goal of the convention should be elimination of POPs releases, as opposed to "management of risks" that POPs pose to humans, wildlife and ecosystems. ${ }^{136}$ IPEN member groups further insisted that the delegates at the negotiating sessions adopt a no-tolerance policy for POPs and work toward their rapid elimination wherever possible. ${ }^{137}$ The practical impact of these strong positions on the outcome of the treaty language is evident, when the provisions are examined in this light.

\section{B. Negotiating the POPs Convention}

IPEN's position and input made strong impressions upon the tone and rhetoric of the INC's first negotiating session (INC-1), as the opening remarks of Dr. Klaus Töpfer, ${ }^{138}$ Executive Director of UNEP, illustrate, showing the shift from language of "POPs management" to POPs elimination. ${ }^{139}$ The first set of meetings ended with delegates adopting the IFCS report and UNEP Decision 19/13C as the man-

133. On the first day of negotiations in Montreal, Greenpeace staged a demonstration in which participants donned costumes and displayed signs identifying themselves as "pregnant bellies for the future," in order to highlight POPs' impacts upon women and developing children. See Lallas, supra note 10 , at 120 .

134. IPEN, POPs Elimination Platform, Aug. 31, 1998, at http://ipen.ecn.cz/ index.php? $z=\& l=e n \& k=$ documents $\& \mathbf{r}=$ viewtxt\&id $=17 \&$ id_rubriky $=12$.

135. Id.

136. Id.

137. Id.

138. .Dr. Töpfer's remarks highlighted the "truly global threat" of POPs and called upon Governments to act decisively, with a goal toward eliminating these pollutants instead of managing them in better ways. UNEP, Report of the Intergovernmental Negotiating Committee for an International Legally Binding Instrument for Implementing International Action on Certain Persistent Organic Pollutants on the Work of Its First Session (July 3, 1998), available at http://www.chem.unep.ch/ pops/pops_inc/inc_l/incl finalreport-e.htm.

139. See Jack Weinburg \& Claudia Saladin, IPEN Report from the First Session of the Intergovernmental Negotiating Committee (INC) on POPs, at http://www.ipen.org (last visited Feb. 13, 2003). 
date and guiding documents for the treaty regime. ${ }^{140}$ While topics such as financial assistance and shared responsibility were raised and discussed at these meetings, concrete concerns about them that would create extreme tension between negotiators in later INC sessions had not yet emerged. In fact, by the end of the weeklong INC-1 session on July 3, 1998, the POPs negotiations were off to a good start, and a significant amount of business was accomplished in the first few days. ${ }^{141}$ Even more remarkable was the extensive public participation in INC-1, a theme that would be repeated throughout the negotiations. At the first meeting alone, fifty-five organizations were represented, with close to one hundred participants. ${ }^{142}$

Domestically, the POPs negotiations seemed to enjoy strong political support from the Clinton Administration, ${ }^{143}$ with a U.S. delegation led from 1998 to 2000 by Brooks Yeager, a well-known environmentalist. ${ }^{144}$ Indeed, a general "environmental" policy orientation was part of an image that Bill Clinton and Al Gore fostered during their bid for re-election in 1996. ${ }^{145}$ Despite the Clinton Administration's claim to have initiated and led the POPs negotiations, ${ }^{146}$ how-

140. See id.

141. See id. ("Not a single country of the 100 or so present[] expressed reservations about the need for an effective global agreement on POPs.").

142. See Lallas, supra note 10, at 114. Many more NGOs were represented at the negotiations by the IPEN network, which consisted of a vast coalition of public health and environmental NGOs. For a list of endorsing organizations, see IPEN Website, supra note 129.

143. In early 1998, officials in the State Department and the EPA announced the Administration's support for the POPs negotiations, proposing to take the lead in addressing issues posed by POPs. See Environmental Media Services, Global Treaty to Ban, Restrict World's Worst Chemicals Will Be Negotiated by 100-Plus Nations This Month, May 28, 1998, at http://www.ems.org/pops/ zz.fenton.98.05.28.html.

144. Brooks Yeager was a Vice President for the Audubon Society before joining the Clinton Administration in 1993. See Henry Lamb, POPs May Be Hazardous to Your Lifestyle, ENTERStageRIGHT.COM, Apr. 30, 2001, at http://www.enterstageright.com/archive/articles/0501 pop.htm. For Yeager's perspective on some issues in the POPs negotiations, see U.S. Statement on Persistent $O r$ ganic Pollutants Treaty, Dec. 10, 2000, at http//usinfo.state.gov/topical/global/environ/latest/ 00121001.htm [hereinafter U.S. POPs Statement].

145. "I want an America in the year 2000 where... no parent should have to worry about the safety of a child's glass of water, and no neighborhood should be put in harm's way by pollution from a nearby factory." President William J. Clinton, Aug. 28, 1996, available at http:// clinton3.nara.gov/ceq/accomp.html.

146. E.g. President William J. Clinton's State of the Union Address, Jan. 27, 2000, available at http:// clinton4.nara.gov/wh/sotu00/sotu-text.html; see also Protecting the Global Environment, May 1997, available at http://clinton4.nara.gov/textonly/ceq/earthday/ch7.html (claiming that the Administration was "leading international negotiations to phase out 12 of the most dangerous, [POPs]."). 
ever, further negotiations would reveal that its position was not always as "green" as the Administration sought to portray.

The second negotiating session of the INC (INC-2) was held in Nairobi, Kenya, during January 1999. This session emphasized concerns for women's and indigenous people's health, and connected concerns over POPs in the environment with data showing harm from exposure to women and other at-risk groups. ${ }^{147}$ Health professionals also gathered at INC-2 to discuss the medical science concerns related to POPs, particularly with respect to DDT use and alternatives in controlling malaria. ${ }^{148}$ Perhaps most importantly, INC-2 engaged developing countries, educating their delegates about risks and alternatives to POPs, encouraging their participation in the implementation phase of the treaty, and learning about their experiences with pesticide POPs. ${ }^{149}$

One issue raised at INC-1 would form the basis of some disagreement at later negotiating sessions. The issue of elimination of various POPs, as opposed to mere management of the risks associated with them, divided delegations at INC-2. While most of the 103 governments represented at INC-2, as well as environmental, public health, indigenous peoples, and women- and consumer-focused NGOs, supported "elimination" of POPs as a core goal of the treaty, some governments-specifically those of the United States, Canada, and Australia-and the chemical industry appeared to argue against elimination, even as a long-term goal, for certain POPs. ${ }^{150}$ Observers, wary that the ostensibly pro-environment U.S. delegation was avoiding the elimination goal shared by most participants, urged the Administration to work for outright elimination of POPs instead. ${ }^{151}$

As evidenced through accounts of the early negotiations, NGOs played an important role at INC-2, making interventions on other key points, including

147. IPEN, Report of IPEN Activities and Accomplishments at the Second Session of the Intergovernmental Negotiating Committee on POPs (Jan. 23-29, 1999), at http://www.ipen.org/inc2.htm.

148. Id.

149. Id. ("Participants remarked at the balance between African and outside presenters, scientists, and activists.").

150. See WWF, Global POPs Treaty Talks (cursory summary of negotiations), at http:/ www.worldwildlife.org/toxics/progareas/pop/global.htm (last visited Feb. 13, 2003) (on file with author). Parties opposing broad "elimination" language in the POPs Convention argued that stopping all production of chemicals such as dioxin (which are externalities of chlorine-based processes) was not feasible.

151. See Nancy Dunne, Clinton 'Weak' on Chemicals Policy, Fin. Times (London), Mar. 21, 2000, at 10 . 
the need for safe alternatives to POPs like DDT, information exchange, and transparency, to name a few. ${ }^{152}$ Like INC-1, INC-2 ended without significant division over many of the final treaty provisions, marked by rapid education and developing consensus over most of the issues that concerned the negotiators.

\section{Emerging Tensions and the DDT Dilemma in Geneva}

At the third INC session (INC-3), held in Geneva, Switzerland on September $4-11,1999$, negotiations over the actual text of the treaty took place. ${ }^{153}$ In Geneva, further tensions emerged between various groups and countries participating in the negotiations. Some of this tension crystallized in debates over the pesticide DDT, which many in the media characterized as the most contentious issue in the negotiations. ${ }^{154}$ Long banned in the North, DDT is widely regarded as a deadly poison. ${ }^{155}$ DDT is used extensively and effectively, however, in combating malaria, a disease that ravages the developing world. ${ }^{156}$ While alternatives to DDT — such as synthetic pyrethroids-are readily available, they are

152. See WWF, supra note 150.

153. IPEN News, Critical Period for Global POPs Negotiations (Nov. 1999), at http// www.ipen.org/ipennews 1 199.htm [hereinafter IPEN INC-3 Report].

154. Indeed, several issues were much more significant, but received less popular attention in the press. See e-mail from Richard Liroff, WWF, to Andrew Yoder (Feb. 21, 2002, 17:20 EST) (on file with author) [hereinafter Liroff E-mail]; see also Thurow, supra note 53, at A6 (describing the conflict between the developing world's use of DDT to combat malaria and the developed world, who sought to "ban DDT completely" through the POPs Convention).

155. See Amir Attaran et al., Balancing Risks on the Backs of the Poor, 6 Nature Med. 729 (2000) ("Few chemicals stir the feelings of the 'man on the street' quite like DDT.").

156. See Henk Bouwman, Malaria Control and the Paradox of DDT, 8 Afr. Env't. \& Wilduife (May 2000), http://www.icps.it/english/bollettino/psn00/000303.htm (asserting that every year, more than 275 million people develop clinical malaria). "DDT remains legal for use [in malaria control] in Bolivia, Venezuela, Mexico, Kenya, Tanzania, Ethiopia, Sudan, Mauritania, India, Nepal, Thailand, Malaysia, Vietnam, and the Philippines, but is apparently available (and not always well-marked) in other nations as well." Mayer, supra note 32, at 173. For more background on malaria and efforts to treat the disease, see WHO, Malaria Fact Sheet No. 94 (revised Oct. 1998) (estimating over one million deaths a year from malaria), at http://www.who.int. Of the estimated one million malaria deaths per year, more than $90 \%$ of these deaths occur in Sub-Saharan Africa, and almost all are children under five years of age. See World Bank Report, Malaria-At-A-Glance, (July 26, 2001), available at http://mosquito.who.inv/cmc_upload/0/000/014/813/malaria_at_a_glancel.htm. 
more expensive and in some cases less effective than DDT. ${ }^{157}$ Many of these alternative chemicals have undergone only limited efficacy testing, and may have more acurely toxic effects than DDT, which is associated with reproductive effects and long-term cancer risks. ${ }^{158}$ These factors combined in the treaty negotiations to produce contentious debate about the fate of DDT in the POPs Convention. Despite accounts in the popular press, however, observers of the negotiations indicate that the DDT issue was never framed in a black-andwhite, "to ban or not to ban" debate. ${ }^{159}$

Prior to INC-1, the World Health Organization (WHO) had been asked to participate in order to lend its significant public health expertise to the negotiations. ${ }^{160}$ Interestingly, the way that the WHO's perspective evolved parallels the way negotiations progressed on the issue of DDT. When the INC-3 talks began, some participants recommended setting a phase-out date for DDT, in the context of a larger set of actions to ensure that efforts to combat malaria were not hindered. ${ }^{161}$ This move to ban DDT use was countered by representatives from de-

157. See Cowling, supra note 54, at 272; see also Donald R. Roberts, DDT Risk Assessments, 109 Envtl. Health Persp. A302 (200I) (arguing that lack of viable alternatives to DDT should come as no surprise and that "global vilification of DDT eliminated almost all research on public health insecticides"). Despite potential problems associated with ill effects from DDT use, the WHO continues to recommend DDT for vector control in combating malaria. See Problems with Persistent Organic Pollutants: Towards Better Alternatives, IFCS Experts Meeting on POPs (Manila, Phil., June 17-19, 1996), available at htrp://www.chem.unep.ch/pops/indxhtms/ifcsall.html.

158. See Matthew P. Longnecker et al., DDT Use in U.S. Linked to Premature Births in the 1960', NIEHS Press Release, July 12, 2001, at http://www.niehs.nih.gov/od/news/preddt.htm; see also WEDO, Special Impacts of Persistent Organic Pollutants (POPs) on Women, available at http:// wedo.orgehealth/popsprimer (citing studies showing decreased lactation and increased risk of breast cancer in women exposed to DDT). For a different take on research linking breast cancer to DDT exposure, see Francine Laden et al., 1,1-Dichloro-2,2-bis(p-chlorophenyl)ethylene and Polychlorinated Biphenyls and Breast Cancer: Combined Analysis of Five U.S. Studies, 93 I. Nat'L Cancer INST. 768 (2001) (combining data from five large breast cancer studies and finding no link to the pesticide DDT). Cf. Pesticide Action Network North America, Study Shows Link Between DDT and Early Puberty, 11 Global Pesticide Campaigner (2001), at http:/panna.igc.org// resources/gpc/gpc_200112.11.3.29.dv.html.

159. See Liroff E-mail, supra note 156; see also E-mail from Cynthia Palmer Olsen to Andrew Yoder (Feb. 11, 2002, 11:08 EST) (on file with author).

160. See Cowling, supra note 54, at 269.

161. See Lallas, supra note 10 , at 133. The WWF, an international environmental NGO that participated heavily in the negotiations leading up to Stockholm, initially called for an international phase-out of DDT by 2007, "as a motivational tool." WWF, WWF's Efforts to Phase Out DDT, at http://www.worldwildlife.org/toxics/progareas/pop/ddt.htm (last visited Feb. 13, 2003). 
veloping countries, who argued forcefully for DDT's continued use, at least until alternatives become affordable. ${ }^{162}$ These countries maintained that DDT's practical and economic effectiveness should exclude it from a complete ban, a perspective that was echoed by some public health officials as well. ${ }^{163}$ Amir Attaran, a lecturer at the Harvard Center for International Development, argued that what he perceived to be a campaign to ban DDT, mounted by hundreds of environmental groups, was premised on a naïve mandate to eliminate DDT altogether, without regard for its beneficial applications. ${ }^{164}$ Attaran, along with health officials and developing country representatives, emphasized the uncertain nature of much of the science behind what participants knew of POPs' effects, arguing that it is not good health policy to stop a known beneficial use based on uncertain harms. ${ }^{165}$

As the negotiations progressed, representatives from developed countries, along with environmental and many public health NGOs from around the world, ${ }^{166}$ focused on the need for precaution in addressing DDT. From the start, negotiators agreed on a ban on DDT for agricultural use, while some NGOs debated its use for malaria control. ${ }^{167}$ These and other public health and environ-

162. See Awounda, supra note 57 (quoting Mozambique's Minister for the Environment, stating, "We cannot get rid of the DDT... overnight. It will take years."). African nations especially, banded together and engaged extensively in the debate over DDT, submitting draft proposals that are reflected in the final treaty. See Lallas, supra note 10, at 133-34.

163. See D.R. Roberts et al., DDT House Spraying and Re-Emerging Malaria, 356 Lancet 330 (2000), at http://www.thelancet.com (emphasizing DDT's extreme effectiveness and, thus, importance to countries battling malaria); see also Attaran et al., supra note 155 (arguing that scientific litcrature supporting a DDT ban was unpersuasive and that the benefits of DDT in saving lives are well worth its risks).

164. Amir Attaran \& Rajendra Maharaj, DDT for Malaria Control Should Not be Banned, 321 BRIT. MED. J. 1403 (2000), at http://www.bmj.com (highlighting the extreme effectiveness of DDT at reducing incidence of global malaria and chiding environmental groups for their "stunningly naive" crusade to prohibit the use of DDT).

165. Id.; see also, e.g., Roberts et al., supra note 163, at 330-32.

166. See Attaran \& Maharaj, supra note 164 ("The campaign to ban [DDT] joined by 260 environmental groups reads like a who's who of the environmental movement and includes names such as Greenpeace, Worldwide Fund for Nature (WWF), and (ironically) the Physicians for Social Responsibility."). A coalition of environmental NGOs formed in 1998, calling itself the International POPs Elimination network (IPEN); grew to embrace more than 300 NGOs, including many from developing countries, by the end of negotiations. See IPEN — About IPEN, at http:// ipen.ecn.cz/index.php?k=about/ (last visited Feb. 13, 2003) [hereinafter $A$ bout IPEN].

167. See The DDT Question, 356 Lancer 1189 (2000) (particularly Richard A. Liroff's response to D.R. Roberts on the malaria issue) [hereinafter The DDT Question]. Among NGOs, the WWF advocated a ban on DDT, but later retreated from this position. See supra notes 161-63 and 
mental groups were represented by IPEN, whose numbers had grown to over 240 member organizations by the end of INC-3. ${ }^{168}$ IPEN also counted among its ranks indigenous groups from developing countries across the globe, who added their perspectives to the debate over DDT and the other POPs. At INC-3, WWF shifted away from its phase-out language for DDT, but continued to emphasize alternative strategies for malaria control, including other types of chemical insecticides and integrated vector management, ${ }^{169}$ and urged clear commitments to increased funding for malaria control. ${ }^{170}$ Health experts related recent knowledge on the process of endocrine disruption and expressed concern over the effects of indoor spraying for mosquitoes - the primary method of employing DDT in combating malaria-but acknowledged DDT's apparent effectiveness and the lack of proven alternatives. ${ }^{171}$ In the end, DDT's continued

accompanying text; see also Summary of the Third Session of the INC for An International Legally Binding Instrument for Implementing International Action on Certain Persistent Organic Pollutants, 15 Earth Negotiations Bull. I (1999), available at http://www.iisd.ca/linkages/voll5/ enb1527e.html. See generally Risk Versus Risk: Tradeoffs in Protecting Health and the EnviRoNment (John D. Graham \& Jonathan Baert Wiener eds., 1995) (giving a thoughtful analysis of the process of risk balancing).

168. IPEN INC-3 Report, supra note 153. IPEN would eventually grow to embrace more than 350 NGOs, including significant numbers from developing countries, by the end of negotiations. See About IPEN, supra note 166.

169. UNEP defines Integrated Vector Management (IVM) as follows:

IVM delivers tailor-made, flexible solutions to local malaria problems, while reducing the use of insecticides whenever possible. IVM is based on clear decisionmaking criteria and management procedures that ensure the best local mix of alternative products and methods at any given time. It requires partnerships with other public sectors, with the private sector and with civil society, and it is therefore compatible with the basic principles of WHO's Roll Back Malaria initiative.

UNEP, Progress Report on the Development of a WHO Action Plan for the Reduction of Reliance of DDT Use for Public Health Purposes, at http://www.pops.int/documents/meetings/inc3/infenglish/inf3-15/inf15.pdf.

170. See WWF, Resolving the DDT Dilemma: Protecting Biodiversity and Human Health, pt. D (1998), available at http:/www.worldwildlife.org/toxics/pubres/ddt l.pdf (offering a framework to guide malaria control programs toward reduced reliance on all pesticides). The WWF dropped its discussion of a ban by 2007 in order to "allay fears" that DDT would be phased out without sufficient guarantees of protection against malaria. WWF's Efforts to Phase Out DDT, supra note 161.

171. See Richard A. Liroff, Reduction and Elimination of DDT should Proceed Slowly, 321 BRIr. Med. J. 1403, 1405 (2000), available at http://www.bmj.com/cgi/content/full/321/7273/1403\#resp2 (warning of house spraying's effects and suggesting that the POPs treaty "raises a series of equity challenges that must be addressed directly"). 
effectiveness and uncertainty about the universal availability of effective, affordable alternatives to DDT shifted the focus away from a DDT ban towards combating malaria through other means. ${ }^{172}$

While there was some dispute over the elimination issue with regard to DDT, there was considerably more consensus about what to do with the other POPs identified by UNEP. Based on the high degrees of persistence and toxicity of those POPs, scientists were in general agreement about the rest of UNEP's "dirty dozen," which include seven other intentionally produced pesticides, dioxins, PCBs and furans. ${ }^{173}$ These compounds have been associated with a wide range of health effects, none of which is balanced by public health applications similar to those of DDT. ${ }^{174}$ Worse, many of the other pesticide POPs are significantly more toxic than DDT. ${ }^{175}$ In fact, the orher pesticide POPs remained in use only because of their availability and relatively low prices, which make them viable options to cash-strapped developing countries. ${ }^{176}$ As a result, negotiators agreed without significant debate about the fate of most of these compounds. By the end of INC-3, parties had reached a preliminary agreement to eliminate production and use of the pesticides aldrin, endrin and toxaphene, for which none of the countries indicated an intention to claim an exemption, ${ }^{177}$ and to phase out chlordane, dieldrin, heptachlor, mirex and hexachlorobenzene with exemptions for certain countries. ${ }^{178}$

Industry representatives continued to speak in favor of continued use of $\mathrm{PCBs}$, arguing that the likely excessive costs of replacing equipment, as well as the PCBs' stability and fire-resistant nature, made them the perfect industrial chemical. ${ }^{179}$ Concerns of cost alone, however, are insufficient to sustain a challenge to

172. See, e.g., WWF's Efforts to Phase Out DDT, supra note 161.

173. See McGinn, supra note 3 , at 80 (providing a table illustrating POPs' persistence and toxicity in relation to other types of pollutants).

174. See supra text accompanying notes 22-50; see also AlLSOPP ET AL., supra note 21, at 5, Box 1.3 (discussing toxic effects of POPs).

175. See A.G. Smith, How Toxic Is DDT?, 356 LANCET 267 (2000) (discussing DDT's toxicity and comparing it to dieldrin, which is thought to be three times more acutely toxic than DDT).

176. These low prices of pesticide POPs are probably due to the fact that the patents on them have expired, allowing cheaper competitors to drive prices down. See Cowling, supra note 54, at 272-73.

177. See WWF, supra note 150.

178. Id.

179. See Lauren MacLanahan, Polychlorinated Biphenyls and the "Mega Rule"-Will it Have the Mega-Impact the EPA Desired?, 24 W. \& Mary Envtl. L. \& Pol'y Rev. 345, 346 (2000) (discussing PCB's characteristics in the context of the U.S. TSCA legislation). 
regulation of compounds, such as $\mathrm{PCBs}$ that are considered highly toxic, are probable human carcinogens, and lead to numerous reproductive and other health problems. ${ }^{180}$ Aside from the DDT issue, a comparison of the risks of further exposure to POPs and the risks of banning their use supports elimination. ${ }^{181}$ In the end, no compelling arguments were made for the continued use of the other chemicals, and a comparison of their costs and benefits weighed heavily in favor of phaseouts or complete bans. ${ }^{182}$

Near the end of INC-3, while many issues had been resolved, great tension remained over other issues, including how to provide technical and financial assistance and the extent to which the precautionary principle should be employed in adding new chemicals to the treaty in the future. ${ }^{183}$ In an attempt to establish consensus on the latter issue, a group of experts proposed scientific criteria for adding chemicals to the agreement during the meetings in June and September 1999, using toxicity and capability for long-range transport as principal criteria. ${ }^{184}$ However, various delegations, most notably the Australian and EU delegates, disagreed about these provisions. ${ }^{185}$ The European Union favored provisions that would make it easier to add new chemicals, even if there were uncertainties about their adverse effects. ${ }^{186}$ On the other hand, the Australian delegation, which appears to have been joined by the U.S. and Canadian delegations and industry representatives, favored an approach involving more steps to adding further chemicals, with no reference to a precautionary principle in the Convention. ${ }^{187}$ However, statements made later by the U.S. delegation indicat-

180. See Harte et al., supra note 6, at 382-84; see also Aaron Wildavsky, But Is It True? A Citizens Guide to Environmental Health and Safety Issues (1995).

181. For background on comparative risk assessment, including pitfalls and potential solutions, see generally Adam M. Finkel, Comparing Risks Thoughtfully, 7 Risk: Health, Safety \& Env't 325 (1996).

182. See The DDT Question, supra note 167 (advocating a risk-benefit approach).

183. IPEN INC-3 Report, supra note 153. Other than dioxin and DDT, the international community was generally in consensus about the other POPs, for which there was not the same continuing need. The inclusion of a "precautionary principle" would prove to be a particularly challenging issue facing negotiators at INC-4 in Bonn, Germany. See IPEN, Press Release, Global Treaty on Toxic Chemicals Moving Too Slowly with Too Many Divisions, at http://www.ipen.org [hereinafter IPEN INC-4 Press Release].

184. See Mayer, supra note 32, at 176.

185. Id.

186. Id. at $176-77$.

187. Greenpeace Toxics Campaign, Stockholm Convention-Australia: The Bad Guys, at http:// archive.greenpeace.org. 
ing that the concept of precaution "fully informs this treaty" call this characterization into question. ${ }^{188}$ Regardless, the question of precaution in the addition of new chemicals would remain contentious through the end of negotiations in Johannesburg the following year.

At the close of negotiations in INC-3, some deliberation still focused on what to do about DDT, and whether its extensive use in malaria mosquito control could be replaced with effective alternatives. ${ }^{189}$ But much of the debate that remained was over even more divisive issues that would play themselves out in later negotiations. ${ }^{190}$

\section{Deep-Seated Divisions in Bonn}

These issues arose in earnest at the fourth INC session (INC-4), which was held March 20-25, 2000, in Bonn, Germany. ${ }^{191}$ During INC-4, many participants shared the perspective that divisions in the negotiations over funding commitments and other issues threatened future progress. ${ }^{192}$ IPEN and member organizations identified several other key disputes, including language on elimination and application of the precautionary principle, and were fearful that dissension among parties would threaten the outcome of the negotiations. ${ }^{193} \mathrm{Clifton}$ Curtis, Director of WWF's Global Toxics Programme, articulated a fear among NGOs that many delegates were "trying to evade their responsibilities as members of the global community" and that the treaty was "being buried under a blanket of arcane language and loopholes." 194 Public health officials from around the world also weighed in on the negotiations, accusing the U.S. delegation of taking an unacceptably weak position, particularly on the elimination question and issues relating to funding and technical assistance for developing

188. U.S. POPs Statement, supra note 144.

189. See IPEN, National Toxics Network Meeting (1999), at http://www.ipen.org/inc3ntn.html.

190. See Liroff E-mail, supra note 154.

191. WWF, supra note 150; see also UNEP, Persistent Organic Pollutants, at http://irptc.unep.ch/ pops.

192. See IPEN INC-4 Press Release, supra note 183.

193. See id. (warning that if disputed issues were not resolved, the result would be "a treaty that is not worth the paper it is written on").

194. Id. 
countries. ${ }^{195}$ Romeo Quijano, M.D., of the Pesticide Action Network of the Philippines, put it bluntly: "It is time to put the money on the table and decide how to get crucial assistance to the developing countries. . . Financial and technical assistance must be recognized as an obligation and not just a handout."196

As they had begun to in earlier INC meetings, negotiators also differed over how to include a precautionary principle with respect to chemicals to be added to the regime after its entry into force. ${ }^{197}$ Indeed, negotiations over precaution and the elaboration of Principle 15 of the Rio Declaration ${ }^{198}$ proved to be one of the most contentious issues addressed at these meetings. ${ }^{199}$ Many environmental group participants stressed the need to enshrine the "precautionary principle" in international environmental law, focusing on verified effects in animals and the potential for negative health effects in humans. ${ }^{200}$ Some public health figures, however, argued that NGOs were employing the precautionary principle to the detriment of Third World health, and questioned the motives of groups that would put the health of people in poor countries "at a very real risk to protect citizens of wealthier nations from a theoretical risk." 201 As they had at previous INC sessions, state delegations also differed in their positions on this issue. The European delegates favored extensive, repeated references to precaution and the "precautionary principle" in the actual text of the treaty. ${ }^{202}$ Other state delegations, including those of the United States, Australia and Canada, favored a riskassessment approach with more proof of causality with regard to listing of new

195. See Environmental Media Services, Public Health Experts Call on Clinton-Gore Administration to Improve Weak U.S. Stance at Treaty Talks on Toxins, Mar. 20, 2000, at http://www.ems.org/ pops/ zz.ems.00.03.20.html (quoting Dr. Peter Orris, University of Illinois Professor of environmental and occupational health sciences, as saying that the Clinton Administration's "weak" and "confused" position was "remarkably similar" to chemical industry positions on these issues).

196. IPEN INC-4 Press Release, supra note 183.

197. See The DDT Question, supra note 167, at 1189-98 (showing different perspectives on the precautionary principle in the POPs negotiations); see also Mayer, supra note 32, at 159-79; see also McGins, supra note 35 (providing an argument that environmental law should reflect a precautionary approach).

198. See Rio Declaration, supra note 90, princ. 15.

199. See Gilbert M. Bankobeza et al., Environmental Law, 35 Int'L Law. 659, 666 (2001).

200. See IPEN, POPs: The Birth of a Public Health Treaty (2000) (arguing that throughout the negotiations, a precautionary approach to POPs was vital), at http://www.ipen.org/treaty02.html. 201. Anonymous Editorial, Caution Required with the Precautionary Principle, 356 LANCEt 265 (2000).

202. Bankobeza et al., supra note 199 , at 667 . 
chemicals. ${ }^{203}$ Despite their efforts, negotiators were once again unable to resolve this issue in the context of INC-4, and the extent to which precaution should be employed in adding new chemicals to the Convention would occupy negotiators in Johannesburg until the final hours of the fifth INC session (INC-5).

By the end of INC-4, however, most of the delegations had reached fundamental agreement on a majority of the issues confronted in the INC sessions. They had expressed their commitment to elimination of non-DDT POPs, embraced at least one version of the precautionary approach, and agreed on confronting the tough issues POPs regulation posed to the global communityeven if they had not solved them yet. ${ }^{204}$

\section{E. Building Consensus (or Buying Compromise) in Johannesburg}

As the debates progressed at INC $-5,{ }^{205}$ and more views were shared, groups and delegations worked to establish treaty language that would be universally acceptable. ${ }^{206}$ On the issue of adding further chemicals to the treaty, the United States and the European Union, in debates that were watched by the media and policymakers across the world, still disagreed about the application of the precautionary principle to the addition of new chemicals to the Convention. ${ }^{207}$ Throughout the entire process, the European Union had proved more progressive and precautionary in its negotiating positions than did the United States. ${ }^{208}$ In the final negotiating sessions, the EU delegation proposed that the process of information-gathering should begin as candidate chemicals are identified,

\footnotetext{
203. See id.

204. See IPEN, Table, National Government Commitments on Elimination and on the Precautionary Principle (Mar. 25, 2000), at http://www.ipen.org/matrix.html [hereinafter IPEN table].

205. Held in Johannesburg December 4-9, 2000, INC-5 was a crucial turning point in the POPs negotiations, with delegates recognizing the need to agree on concrete language and reach compromise on important parts of the treaty provisions.

206. See IPEN table, supra note 204 (indicating a majority of state delegations were in favor of eliminating most POPs and enshrining the precautionary principle); see also Lallas, supra note 10, at 133 .

207. See Vanessa Houlder, Deal in Sight over Toxic Chemicals Treaty: African Exemptions for Malaria Control Are Adding to Tensions at Johannesburg Meeting, Fin. Times (London), Dec. 7, 2000, at 15 .

208. UN Conference Approves POPs Convention in Stockholm, OurStolenFuture.Org (describing European and U.S. divergences on several issues), at http//www.ourstolenfuture.org/policy/ pops/2001-0522popsconvention.htm (last visited Feb. 13, 2003).
} 
hoping to speed up the process of listing new POPs to regulate under the auspices of the Convention. ${ }^{209}$ The U.S. proposal-which was advocated by the G-77 nations after strong U.S. lobbying behind the scenes-alarmed some observers of the negotiations, who warned that under this procedure, it was unlikely that new chemicals would be included formally and thus earmarked for bans for at least a decade. ${ }^{210}$ Negotiators finally agreed to this proposal, adopting provisions to add new chemicals that resemble the risk-assessment approach advocated throughout by industry and the U.S. and Australian delegations. ${ }^{211}$ In this way, application of precautionary language relating to the addition of new chemicals to the Convention was the product of careful compromises reached over the course of long negotiations. ${ }^{212}$ In the end, the final version of the Stockholm Convention includes several references to the precautionary principle in the preamble, objectives, and provisions concerning review and listing of additional chemicals. ${ }^{213}$ Since it applies the precautionary principle to toxic chemical management in international law, the Stockholm treaty represents an important milestone in international environmental law. ${ }^{214}$

Even with progress on divisive questions related to DDT and the precautionary principle, negotiating parties at INC-5 faced daunting issues of financial and technical assistance that had yet to be resolved. Throughout the process, it was clear that POPs were of greater concern to developed countries, despite the risks POPs posed to developing countries. ${ }^{215}$ For this reason, most of the participants

\section{Id.}

210. Id. This fear was not shared by many participants, however, and there is significant evidence of will to move forward with the addition of new chemicals once the treaty enters into force. See Resolutions Adopted by the Conference of Plenipotentiaries on the Stockholm Convention on Persistent Organic Pollutants, II.8, available at http:/www.pops.int/documents/implementation/ resolution/default.hrm.

211. Bankobeza et al., supra note 199, at 666; see also Written Testimony of Michael Walls, for the American Chemistry Council Before the Senate Committee on Environment and Public Works on the Stockholm Convention on Persistent Organic Pollutants (May 9, 2002), available at http:// www.senate.gov/ - epw/walls_051402.htm.

212. Testimony of Brooks Yeager, Vice President for Global Threats, WWF, Before the Comm. on Environment and Public Works, U.S. Senate 4-6 (May 9, 2002), at http://www.worldwildlife.org [hereinafter Testimony of Brooks Yeager].

213. Bankobeza et al., supra note 199, at 666.

214. McGinn, supra note 3, at 76.

215. Delegates from these countries, while acknowledging POPs' risks for the developing world, noted that the risks paled in comparison to those posed by poverty, AIDS and other, more immediate threats to health and security. Bankobeza et al., supra note 199, at 667 . 
understood that funding commitments were essential to secure the participation of poorer countries. Not all developed countries shared this view, however. Indeed, the EU delegation initially opposed funding commitments, arguing against trading funds for compliance. ${ }^{216}$ Most delegations expressed concern not about whether to provide technical assistance or to which states it would be distributed, but about the level and the method by which it would be administered.$^{217}$ Among these parties, the real debate related to the suitability of the Global Environmental Facility (GEF), over which many countries expressed unease. ${ }^{218}$ In the end, as part of a political compromise, the GEF was chosen as an interim agency to coordinate financial and technical assistance, with the Conference of the Parties agreeing to revisit the effectiveness of the institution at its first meeting. ${ }^{219}$

During the week of June 17 to 21,2002, parties met in Geneva for the sixth INC session (INC-6), which was designed to coordinate efforts to implement the Stockholm Convention, signed in Stockholm in May 2001. ${ }^{220}$ During this set of meetings, the groundwork was laid for execution of the various provisions of the Convention, including, the review process for specific exemptions, guidance on a number of technical issues, and procedures for reviewing the GEF (the interim funding and technical assistance facility). ${ }^{221}$ INC- 6 marked the end of the negotiation phase and the beginning of the implementation phase for the new POPs Convention, with delegates working together with a renewed purpose to implement the provisions of the treaty as soon as possible. ${ }^{222}$

216. See E-mail from Morag Carter, IPEN coordinator, to Andrew J. Yoder (Feb. 18, 2002, 12:30 EST) (on file with author).

217. Id.; Testimony of Brooks Yeager, supra note 212 , at 5.

218. IPEN website, supra note 129; see also Testimony of Brooks Yeager, supra note 212, at 5.

219. Stockholm Convention, supra note 1, art. 14; accord Testimony of Brooks Yeager, supra note 212.

220. UNEP, Report of the Intergovernmental Negotiating Committee for an International Legally Binding Instrument for Implementing International Action on Certain Persistent Organic Pollutants on the Work of its Sixth Session, at http://www.chem.unep.ch/sc/documents/meetings/inc6/en/ meetdocen.htm.

221. See POPs INC-6 Meeting Documents (providing a complete list of topics at the INC-6 meetings), available at $\mathrm{http} / / \mathrm{ww}$ w.chem.unep.ch/sc/documents/meetings/inc $6 / \mathrm{en} /$ meetdocen.htm.

222. UNEP, supra note 220. 


\section{Drawing Lessons from the Stock holm Experience}

Participants in the POPs negotiations reached compromise in the final hours of the negotiations in Johannesburg, ${ }^{223}$ creating a treaty regime that promises to be the most effective multilateral environmental treaty of the new decade. ${ }^{224}$ Indeed, despite the divergent perspectives on POPs witnessed in the context of the negotiations, the final agreement has been accepted and praised by governmental and public health officials, policymakers, and representatives from both environmental groups and the chemical industry. ${ }^{225}$ This broad consensus is as rare in international environmental law as it is encouraging. Analysis of the broadly accepted regime that negotiators were able to achieve in the Stockholm Convention yields lessons for future MEAs. Whether or not these lessons apply perfectly in other issue contexts, the experience of the POPs Convention illustrates the progress that can be made on global environmental problems.

\section{A. Limits on Effectiveness and Applicability of POPs Convention}

Despite initially positive indications from state parties involved in the negotiations, it is possible that the Stockholm Convention will be less than a complete success. Effective implementation may be circumscribed by shortcomings in ratifying states. The Convention requires that fifty states ratify the treaty before it enters into force, which may prevent meaningful progress from occurring for

223. Mariann Lloyd-Smith, Coordinator, National Toxics Network Inc., Letter Written upon Completion of Negotiations, Dec. 10, 2000, at http://www.ipen.org/treaty01.

224. McGinn, supra note 3, 75-76 (calling the Stockholm Convention one of the "main environmental achievements" since the 1992 Rio Conference and an "important milestone in international environmental law").

225. See id.; see also IPEN, supra note 200 (calling the Stockholm Convention a "strong treaty"); WWF, supra note 150 ("The treaty provisions appropriately balance [competing needs]."); Michael P. Walls, Stockholm Convention on Persistent Organic Pollutants (POPs), Presentation at the Global Chemical Regulations Conference: Living with TSCA and International Chemical Controls (Mar. 14,2001 ) (describing the "generally satisfactory outcome"); President George W. Bush, Remarks by the President, Secretary of State Colin Powell and EPA Administrator Christine Todd Whitman, Address at the Rose Garden press conference (Apr. 19, 2001) (praising the treaty as "the way environmental policy should work"). 
several years, while countries debate the treaty's language and requirements. ${ }^{226}$ In the U.S. context, this process is not open-and-shut, despite early indications of support from the current Bush Administration and signature by EPA Administrator Christie Whitman. ${ }^{227}$ Since official U.S. participation in the treaty requires Senate ratification, the U.S. role in POPs treaty implementation will depend on the language that the legislature eventually approves.

On April 11, 2002, Administrator Whitman announced that President Bush was submitting the Stockholm Convention to the Senate for advice and consent to ratification, beginning the process of legislative review of the treaty. ${ }^{228}$ Upon reviewing the implementing legislation, however, environmental groups expressed concern that the legislation failed to address the addition of new chemicals to the treaty. ${ }^{229}$ In remarks to House Speaker Dennis Hastert, Administrator Whitman responded by indicating that the legislation included a "science-based procedure for the international community to add new chemicals in the future" and asserted that the "details related to implementation of the specific criteria [to add new chemicals] are still under development." ${ }^{230}$

At the time of this writing, two distinct Congressional areas of action are needed to enact the POPs Convention for the United States: funding and final im-

226. See Joel A. Mintz, Two Cheers for Global POPs: A Summary and Assessment of the Stockholm Convention on Persistent Organic Pollutants, 14 Gro. INT'L EnvTL. L. Rev. 319, 331 (2001). Recent ratifications by several parties may belie this assumption, however, and underscore the ways in which the POPs convention is unique. See Stockholm Convention on Persistent Organic Pollutants Homepage, at http://www.pops.int/.

227. "I'm pleased to announce my support for the [POPs] treaty and the intention of our government to sign and submit it for approval by the United States Senate." President George W. Bush, Remarks Regarding the Stockholm Convention on Persistent Organic Pollutants (Apr. 19, 2001), available at http://www.state.gov/ secretary/rm/2001/2356.htm. "The Bush Administration strongly supports the POPs Treaty." EPA, Fact Sheet on POPs (Sept. 2001); see also EPA \& Dept. of State, Press Statement, U.S. Signs Convention on Persistent Organic Pollutants (May 23, 2001), at http://yosemite.epa.gov.

228. See EPA, Press Release, President Bush Sends the Stockholm Convention on Persistent Organic Pollutants to Senate for Ratification; Submits Legislation to Congress to Implement Treaty (Apr. 11, 2002), at http://yosemite.epa.gov.

229. See WWF, Press Release, WWF Applauds Bush Decision to Send Chemical Treaty Package to the Hill, But Legislative Deficiencies Must Be Fixed by Congress (Apr. 10 2002), at http:/ www.worldwildlife.org/toxics/whatsnew/pr_26.htm.

230. Letter from Christine Todd Whitman, EPA Administer, to Speaker Dennis Hastert (on file with author), at http://www.epa.gov/oppfeadl/cb/csb_page/updates/popsletters.htm (last updated Apr. 11, 2002). 
plementing legislation. ${ }^{231}$ In order to fund the interim financial mechanism for the POPs Convention, the Bush Administration in early August, 2002, pledged over $\$ 500$ million to the GEF over four years to ensure that the GEF's other duties are not neglected while it implements the POPs Treaty. ${ }^{232}$ Along with those of thirtyone other countries, the United States' contribution to the GEF will fund the GEF's operations through June 2006, allowing it to continue its important work on biodiversity, climate change, and ozone-depleting substances, while providing additional funds to integrate its new functions under the POPs Convention. ${ }^{233}$

To ensure complete participation by the United States, the Senate must act on the implementing legislation-including the Administration's bill and the Chairman's bill, S.2118 - in order to implement the provisions for adding new chemicals agreed upon by negotiators at INC- $5 .{ }^{234}$ In so doing, however, the Senate must work out differences between S.2118 and the Administration's version of the implementing legislation, which left out the provisions for adding new chemicals, envisioning a case-by-case revision of domestic legislation each time a POP was considered for addition to the Convention. ${ }^{235}$ This hurdle to future implementation of the Treaty must be addressed and removed by the Senate before effective implementation of the Stockholm Convention can take place. Without these changes to the Administration's proposed legislation, U.S. participation in the Convention is threatened, as is its credibility among other nations in the international regulation of POPs. ${ }^{236}$

Weaknesses in the Convention text could also inhibit its implementation. One such weakness lies in the POPs Treaty's cost-recognizing provisions, which in some cases could prevent best available technology from being employed. ${ }^{237}$ The terms of the Convention are also vague on enforcement issues, which could

231. Testimony of Brooks Yeager, supra note 212, at 7.

232. Eryn Gable, Nations Agree to \$3B Enviro Fund Replenishment, Greenwire, Aug. 8, 2002, at http://www.eenews.net/greenwire.

233. See id.

234. See Testimony of Brooks Yeager, supra note 212.

235. See id. (describing alternative ways that new POPs can be regulated under existing U.S. laws).

236. See id.

237. See Mintz, supra note 226, at 331 (citing Stockholm Convention, supra note 1, Annex C, pt. $\mathrm{V}(\mathrm{B})$ ). The language to this effect is ambiguous, however, and should be read merely to advocate cost-benefit analysis; as such, it does not seem to pose much of a threat to effective implementation, given other provisions in the text and the generally precautionary nature of the treaty. See Stockholm Convention, supra note 1 , art. 1. 
lead to ineffectual treaty enforcement mechanisms. ${ }^{238}$ As discussed below, however, unique features of the states and industries most affected by this treaty will likely mitigate this potential weakness and result in relatively strong enforcement. A final place in which the POPs Convention may lack detail is in a tracking system to prevent illegal trade in banned pesticides. Again, this concern, if realized, is likely to pose only a minor impediment to effective operation of the treaty regime, since significant incentives for implementation exist.

It may be difficult for other reasons to derive lessons for negotiating future international environmental treaties from the successes of the POPs experience. One reason that the parties were able to reach agreement may have been the particular circumstances of the parties, the global economy, and the fact that substitutes for many POPs are available. In this way, the Stockholm Convention may be similar to the Montreal Protocol, which was able to garner near-complete consensus due to a number of peculiarities. The Montreal Protocol was able to achieve its relative success due to the particular characteristics of the issue, the parties, and the presence of such widespread support for regulating CFCs. ${ }^{239}$ Further, as with POPs, the chemicals of concern in the Montreal Protocol, CFCs, were produced by humans, and their uses were widespread, but circumscribed. ${ }^{240}$ The potentially affected industries were also generally proponents of regulation, since they were creating substitute products, and they would benefit from the increased demand for them. ${ }^{241}$

The POPs context is similar. While their uses are also widespread, POPs have specific applications in industry and agriculture. As in the development of the Montreal Protocol, industry was not antagonistic in the POPs context, ostensibly motivated by prospects of marketing and selling more costly substitutes to the banned pesticides. Though these factors may prevent the experience from translating broadly into regimes crafted to deal with other types of environmental problems, they do appear promising for the successful implementation of the POPs Convention.

Despite the singularity of many components of the POPs process, several factors may apply broadly to future multinational environmental treaty negoti-

238. See Mintz, supra note 226, at 332.

239. See DeSombre, supra note 93, at 52 (explaining how "remarkably particular" characteristics made the Montreal Protocol possible and may also constrain its applicability to other situations). 240. See id.

241. See id. at $57-58$. 
ation. One early lesson is that each stage of a treaty is important, and the way that the treaty progresses from initial meeting to the signing of the final document is of fundamental importance in determining its outcome. ${ }^{242}$ Throughout negotiations, extensive participation-by representatives of governments, NGOs, and affected industry - can make all the difference in MEAs. It is also important to maintain this involvement throughout negotiations by taking account of states' limitations and accounting for them through creative provisions. Finally, a focused legal mandate is also needed to keep the treaty negotiation process on track, creating a direction to guide participants.

\section{B. Encouraging Participation-A Way to Success}

The lessons that can be drawn from Stockholm begin with the way that the treaty developed, even before the substantive negotiations began. Several novel features of the Convention allowed a broad range of perspectives to be represented at the negotiating table. Early on, UNEP recognized the many limitations to participation in international treaty regimes on the part of developing countries and took steps to overcome these obstacles. Not the least of these involves the expense of fielding teams of negotiators, especially from the smallest and poorest developing countries, whose priorities often involve concerns that are more basic. ${ }^{243}$ UNEP addressed these concerns by providing funding to enable officials from developing countries to attend negotiation sessions and preparatory and informational meetings around the world. UNEP also scheduled regional workshops with the same goals in mind, holding two of the five INC sessions in Africa, and one of the two meetings of the Criteria Experts Group in Thailand. ${ }^{244}$ These actions helped negotiators recognize the perspectives and balance the needs of both developed and developing countries. As illustrated in the DDT context, negotiators balanced the need to reduce pesticide use against the need to protect populations from malaria, and were able to reach a compromise that promises to be workable when implemented.

242. Cf. Lallas, supra note 10 , at 150.

243. See Montevideo Programme II: The Programme for the Development and Periodic Review of Environmental Law for the 1990s, UNEP Dec. 17/25 (May 21, 1993), at http://www.unep.org/ new_law/montevideo\%20programme\%20ii.doc.

244. Lallas, supra note 10 , at 140. 
The POPs negotiations are seen as successful because of the way that they integrated NGOs into the negotiation process. ${ }^{245}$ The international community also sought to facilitate NGO participation by establishing the "POPs Club," an innovative concept designed to ensure that as many voices as possible were heard throughout the negotiations. ${ }^{246}$ The POPs Club set up a fund, combining over five million dollars in donations from governments, intergovernmental organizations (IGOs), and NGOs to facilitate meetings among delegates. ${ }^{247}$ IPEN also worked to leverage resources to bring NGOs from around the world to the sessions. By ensuring participation in initial meetings through these mechanisms, the international community was able to encourage significant attendance and participation in the various INC negotiating sessions. As a result, developing countries' perspectives remained at the forefront to an extent not often seen in MEA negotiations. The result of this increased acknowledgement of Southern perspectives is a regime that strikes a balance between competing needs in a new way.

\section{Crafting Practical Provisions}

The fundamental lesson to be learned is that MEA's provisions need to compel participation, not prevent it. The Stockholm Convention's substantive provisions address the need to ensure participation. ${ }^{248}$ Just as UNEP employed fresh techniques to encourage participation at the negotiation stage, the POPs treaty, as finalized at INC-5 in December 2000, includes features that enhance the abilities of developing nations to comply with treaty requirements. ${ }^{249}$ The Convention includes mechanisms to assist less developed nations that are likely to further effective implementation of the agreement. The most significant of these involve financial assistance provisions, in which developed country parties pledge to provide "new and additional financial resources" to developing countries implementing the Convention. ${ }^{250}$ Indeed, the Convention makes

245. Indeed at the end of the last meeting, John Buccini, chair of the negotiations, identified NGO participation as "one of the hallmarks of the entire process." Id. at 118; see also IPEN website, supra note 129.

246. See UNEP, The POPs Club: An Innovative Financing Mechanism Helping to Bring About a Global Treaty (2001), at http://irptc.unep.ch/pops/pops_club/pops_club.htm.

247. Id.

248. The rest of the substantive provisions are discussed in Mintz, supra note 226, at 326. (providing a summary of the Stockholm Convention's provisions and a brief assessment of its utility). 249. Id.

250. Stockholm Convention, supra note 1, art. 13(2). 
developing countries' implementation of their commitments under the agreement contingent upon the provision of financial assistance by developed countries. ${ }^{251}$ In this way, the Stockholm Convention utilizes a modern technique in international environmental law, creating a legal relationship between the obligations of developing countries and the financial obligations of developed countries, and including unequivocal language to this effect. ${ }^{252}$ In a controversial decision, the negotiators determined that the GEF, which provides financial support to remedy ecological problems, would provide interim operation of the financial arrangements, which they specified in article $13 .{ }^{253}$ The Convention includes provisions to "cooperate to provide timely and appropriate technical assistance to developing country Parties. . ..,"254 a function the GEF will also undertake. In the future, it is likely that most MEAs will require technical and financial assistance provisions in order to secure the participation of the world's less developed countries.

A more general and intuitive observation of the POPs negotiations is that the goals of the treaty regime need to be constructed in terms that make sense to the parties negotiating them. For this reason, complete bans of chemicals in some contexts can be counterproductive. This reasoning applies to DDT in the POPs context, because of its ongoing utility in combating malaria; only after parties agreed to ongoing use of DDT for vector control could negotiations proceed. In its final form, the POPs treaty calls for general elimination of DDT production and use, but provides for country-specific exemptions for vector control. ${ }^{255}$ Parties wishing to continue using DDT for vector control are required to do in accordance with WHO recommendations and guidelines and only "when locally safe, effective, and affordable alternatives are not available to the Party in question." 256 To ensure oversight, reserving parties must submit periodic reports about their use, explore substitute methods, and periodically evaluate the continued need to employ DDT. ${ }^{257}$ Significantly, however, the Con-

251. Id. at art. 13(4).

252. This technique is employed in the Global Convention on Biodiversity, adopted May 22, 1992 , in force December 29, 1993, which made conservation duties contingent upon "new and additional financial resources." Kiss \& SHelton, supra note 97, at 308-09.

253. Stockholm Convention, supra note 1 , at art. 14.

254. Id. at art. 12(2).

255. Id. at Annex B, pt. II(1)-(4).

256. Id. at Annex B, pt. II(2).

257. Id. at Annex B, p. II(5). 
vention does not include a specific phase-out date for DDT, a provision over which considerable debate took place. ${ }^{258}$ As the experience of the POPs Convention has illustrated, however, complete bans can and do make sense in the right context, when appropriate factors are taken into consideration.

Still other lessons can be taken from the form of the treaty itself. It is important to commence MEA negotiations with a focused objective. The way that negotiators developed and carried out a strong legal mandate on POPs holds lessons for future MEAs. By limiting the initial focus to a specific set of "dirty" chemicals, the Stockholm Convention acknowledges the constraints in circumscribing the use of chemicals and focuses its provisions in an in-depth manner, purposely "going deep" in the way it addressed these twelve chemicals, instead of developing a broader toxics treaty. ${ }^{259}$ In this way, negotiators avoided the sometimes problematic framework-protocol approach, often employed in international environmental treaties in order to achieve initial consensus on regulatory prerogatives. Once the framework is established, parties negotiate specific protocols on various aspects of the larger problem. This approach has received criticism for failing to secure effective participation, particularly in the notable example of the Kyoto Protocol. ${ }^{260}$ By incorporating the precautionary principle and empowering institutions to review the regime's progress, the Stockholm Convention ensures that other chemicals will be added to the initial "dirty dozen," but established clear terms and concrete duties with regard to the first twelve POPs. The Convention also institutionalizes performance by organizing a Conference of the Parties to oversee ongoing issues related to implementation.

\section{POPs and the Future}

In light of these provisions, it is not surprising that the final agreement was able to secure strong initial support from nearly 120 states, and now claims over 150 signatories. ${ }^{261}$ As always, the proof will be in the pudding: the true success of

258. Lallas, supra note 10 , at 133.

259. Id at 143.

260. See Nanda, supra note 120 , at 321.

261. POPs Convention Homepage, List of Signatories and Parties to the Stockholm Convention of 2001, May 22, 2001, at http://www.pops.int/documents/signature/signstatus.htm; see also WWF Toxic Chemical Initiative, Global Chemical Conventions: Ratifications, at hitt://archive.panda.org/ toxics/ratify/ (last visited Feb. 13, 2003). 
the Convention will be determined by how effectively parties implement the provisions. As is clear from the Bush Administration's incomplete legislative proposal to implement the treaty in the United States, there are many reasons to be tentative in predicting the ultimate success of the global POPs treaty. The international chemical industry, which opposed strong language throughout the process, now lauds the treaty as an important step in cleaning up the global environment. ${ }^{262}$ This gives one pause to consider how effective the treaty will be at reducing the earth's toxics burden generally. In addition, broad support for the treaty could be due in part to loopholes in the convention's language, which could prevent effective enforcement.

The significant promise, however, that the treaty presents for the reduction of POPs, and the tremendous will to move forward experienced at the signing in Stockholm, bode well for the future of this convention. Of course, the fate of the treaty will depend upon solid domestic implementation, which in turn will require the continued and increased monitoring that brought many of these issues to bear in the first instance. Recalling the significant public support for and recognition of the need to regulate POPs effectively, this monitoring will probably occur. The likely result is an effective global regime on an especially pernicious set of toxic chemicals. The broad support from nearly all sectors working on the POPs Convention encourages optimism about the future of international POPs control. Further, the lessons that policymakers and others can draw from the experience are many, and implementing these in future MEAs is likely to result in more successful environmental accords overall.

262. See, e.g., Walls, supra note 225. 